\title{
Richard II and the Fiction of Majority Rule*
}

\author{
Gwilym Dodd
}

\section{Introduction: The Problem of the King's Youth}

For Thomas Walsingham, one of the first occasions when Richard II revealed the true nature of his rule came in the Summer of 1383 when, accompanied by his new Queen, he went on a 'shrine-crawl' of the eastern counties, imposing himself and his household on the hospitality of the region's abbeys, apparently showing little consideration for the expense and inconvenience which his visits caused. It was not simply that the king had received 'an abundance of gifts from both religious and seculars', but that these gifts had been 'bestowed in great abundance upon the foreign countrymen of the queen, her Bohemians'. ${ }^{1}$ Moreover, when he had stayed at the abbey of Bury (St Edmunds) Richard had peremptorily confirmed Abbot John Timworth in office even though the latter had not yet received papal confirmation. 'After such action', Walsingham commented, 'the king's unreliability, and that of his council, became known far and wide'. All in all, if Walsingham's account represented broader opinion, Richard's progress through the shires had been a public relations disaster. It had exposed some deep-seated flaws in the exercise of his kingship - the unnecessary extravagance of his household, the misappropriation of money and the injudicious exercise of the royal prerogative. Over the next few years these faults would form the kernel of criticism levelled against the king until, in 1386, royal authority was overthrown completely and the king himself was forced into a quasi form of political exile. Perhaps the most telling aspect of this account lies in the explanation Walsingham offers for Richard's apparent excessiveness. It was in light of the king's visit to the shrines of Norfolk and Suffolk that the chronicler uttered those words, now so inextricably associated with minority rule, that a kingdom 
could expect nothing but misfortune if its king was a minor: 'Woe to thee, O land, when thy king is a child'. ${ }^{3}$ The real sting in the tail lay in the fact that by 1383 Richard II was seventeen and a half years old and was, by any measure - contemporary or modern - of sufficient years to be considered an adult. The reference was therefore less an objective statement of fact than a subjective observation on the young king's disposition and abilities: the king, in spite of his age, was not yet mature enough to govern with the wisdom and good judgement expected of an adult. That Richard 'hadn't grown up' formed a common thread in the discourse employed by the opposition to his rule - and for good reason, for it provided a formidable rhetorical strategy to justify interference in decisions and actions that a fully fledged adult king would have expected, and would in normal circumstances have been allowed, to take unhindered. ${ }^{4}$ The king's immaturity is the clear implication behind the threat issued by the Appellants in the Tower of London in 1387, that if Richard did not 'correct his mistakes and henceforward submit himself to the control of the lords ... he must understand that his heir was unquestionably of full age'. ${ }^{5}$ Some weeks later, in articles of accusation levelled against Richard II's courtiers and advisors in the Merciless Parliament of 1388, charges were laid before the assembly on the grounds that, 'seeing the tenderness of the age of our lord the king and the innocence of his royal person, [the king's allies had] caused him to apprehend as truth so many false things ... against loyalty and good faith...' ${ }^{6}$ In this instance, the Appellants were casting themselves in the mould of protectors of the royal dignity and were asserting their political agenda in terms of a legitimate programme of reform to allow for the apparent deficiencies in Richard's rule caused by his youth. It is significant that even as a twenty-one year old the king's inability to discern good counsel from bad was ascribed above all in terms of his age. The king's lack of maturity also constituted a cornerstone of the Lancastrian spin placed on Richard's downfall in 1399. In the critical moments following Henry Bolingbroke's enthronement in the parliament of that year, Archbishop Arundel delivered a sermon to the assembled Lords and 
Commons in which he justified the transfer of power on the premise that 'in the place of a boy wilfully running riot, a man will now rule over the people'. ${ }^{7}$ The significance of the fact that Richard and Henry were both the same age, that is to say 32 years old, has not been lost on historians, ${ }^{8}$ and most certainly it would have been understood by contemporaries: this was what gave the sermon so much force. For Adam Usk, writing with the benefit of hindsight and also with an intimate knowledge of how the Lancastrian regime conceived the reign of Richard II, it was the latter's youthful tendencies which above all explained his downfall: 'during the time of this Richard's youth, both because of it and because of what resulted from it, numerous misfortunes continued to plague the English kingdom ... leading to great confusion in this realm, and, in the end, to the destruction of King Richard himself and of those who clung to him too fondly'. ${ }^{9}$ The underlying subtext was that youth was fundamentally incompatible with successful government. It was an attitude predicated on an assumption that effective rule was dependent on the ability of a king to exercise his will independently so as to be able to balance political factions, to exercise sound judgement and to rule without pandering to the influence of others. ${ }^{10}$ The assumption was that children were inherently incapable of possessing these qualities.

If the subject of the king's youth could be used to justify the course of history in accordance with a political programme espoused by Richard's opponents, it is important to note how the king himself came to use his age as a way of accounting for the problems he had faced in the course of his reign. Both Richard and his opponents considered the king's 'tender years' to have been a weakness, but whereas his opponents projected this as a cause of misgovernance and unsound policy, Richard considered it to have presented opportunities to his opponents to promote their own self-interested ambitions. In a letter written in the winter months of 1397-8 to the count of Holland, in which he rejoiced in his recent coup against the former Appellants, Richard mused that 'posterity may learn what it is to offend the royal majesty, established at howsoever tender years; for he is a child of death who offends the king'. ${ }^{11}$ This reference to the 
circumstances of his accession, twenty years after the event, is significant, for it suggests that for Richard his youth was an important factor in shaping his perception of the course of events since 1377 , only for him this perception was formulated in terms of victimhood and oppression. The Wilton Diptych provides a further clue in this regard, for its unmistakeable depiction of Richard as a boy is surely intended to represent his coronation in 1377 in which his kingdom was 'handed over' by the Christ child, Mary and the heavenly body of angels. ${ }^{12}$ In the mid-1390s, when the Diptych was painted, such a scene would have reinforced the sense not only that Richard's authority lay beyond the encroachment of earthly forces, but also how the king had a divinely appointed mission to restore to himself the untrammelled power and authority which had been invested in his office at the point at which he had been made king in 1377 . The Wilton Diptych was thus a depiction of Richard's kingship in its pure and unblemished state - a position which neatly mirrored the king's own circumstances at the point of accession when he was 'so innocent and tender in age'. ${ }^{13}$

Richard's youth thus informed and in many ways determined the shape of the political controversies of the late fourteenth century. That the king had come to power as a boy was not simply a fact, but a matter of serious and prolonged debate as it came to be seen as a means of legitimising political action. For Richard's opponents, the root cause of the political tensions of these years was the king's failure to develop the critical facilities necessary for a fully functioning adult king; for Richard, it was that his youth had presented opportunities to his adversaries to make good their selfish political ends and in so doing to encroach on his royal prerogative. In essence, one side posited that Richard II had never grown up; the other, that Richard had never been allowed to grow up.

Richard II's reign is almost unique in the attention that was given by contemporaries to the king's age and in particular to the consequences of his youth on politics. It was a debate which, perhaps more than any other reign in which a king ascended the throne as a 
minor, was to have a lasting effect on his rule and on his subsequent reputation. The circumstances of Richard's succession to the crown as a ten year old boy, and the ensuing problems he experienced attracting broad political support, has certainly had a profound impact on the nature and shape of historical writing, as modern historians have come to depict the king as a wilful teenager trying to come to terms with an unhappy and troubled upbringing. ${ }^{14}$ These ambitious, if ultimately futile, attempts to psycho-analyse Richard's personality provide an interesting parallel with contemporary views which held Richard's youth to be the source of all his - and his kingdom's - problems. ${ }^{15}$ The overbearing concentration on Richard's age and his apparently youthful tendencies is to be explained by the fact that there was only a short period of his reign in which he was seemingly at liberty to exercise authority in his own right without the constraints and limitations imposed on him by parliament or his magnates. Whether Richard was a capable ruler or not, the fact that it was not until the 1390 s that he was finally in a position to assert his authority has no doubt reinforced the impression that for much of his reign he was deficient in a number of key areas. Had Richard ruled beyond 1399 the circumstances of his accession and the troubles of the 1380s might well have receded into memory, but the usurpation ensured that his youth, and the problems which were thought to have stemmed from it, remained at the top of the political agenda. In essence, Richard never really had the time or opportunity to shake off the stigma that he was immature and therefore unsuited to exercising authority without the 'help' of advisors.

But all this stemmed from an even more fundamental problem attached to the circumstances of his rule. When he came to power in 1377 a decision was taken to maintain the fiction that Richard ruled as though he were an adult. This meant, in essence, that really important decisions were taken by other people, but were recorded in his name. The paradox of the situation was emphasised by the appointment of the councillors who were charged with the responsibility of day-to-day government soon after Richard became king. The day after his 
coronation Richard witnessed the swearing in of these advisors. On paper at least, this was the king's council, sworn in at his behest and answerable to the king for its actions, but in reality it was the king who was 'ruled' by the council and it was he who required guidance and direction. The arrangements put into place in this year asserted the indivisibility of the king and crown and the basic principle that the crown must be perpetually adult. There were good reasons for these arrangements (as discussed below), but they created a set of circumstances which made it hard for the political community to accept when Richard really was ready to take over the reins of government, and even harder for Richard to assert this himself. Because there was no 'official' minority there could be no 'official' end to the supervision which the political community felt was rightfully theirs to give to Richard during his 'tender years'. The debate about when to end this supervision therefore hinged not on a formal and prearranged date which accorded to a particular age of the king, but rather on his kingly qualities or 'capabilities', which became a matter of judgement and interpretation. It was undoubtedly the ambiguity surrounding Richard's status that above all created the conditions for political conflict and turmoil in the 1380 s. ${ }^{16}$ Even Richard himself seems tacitly to have acknowledged the ambiguity surrounding his abilities in the first twelve years of his reign when, in May 1389, he announced to his council that 'his attainment of fully completed age put him in the position of an heir claiming his inheritance on reaching his twenty-first year'. ${ }^{17}$ It is possible, though difficult to prove, that he may have been influenced by events across the channel, where six months previously, the young Charles VI had staged a similar coup against his own overbearing uncles, asserting his right as a king of almost twenty years old to take control of affairs himself. ${ }^{18}$ In the direct speech attributed to Richard II, he purportedly announced that, 'I think it is fitting that I should ... assume the conduct of affairs, since I have reached the age of maturity'. If this accurately records what was said, ${ }^{19}$ it is striking that Richard himself should have couched his reassertion of authority not in the straightforward language of offended royal dignity but in terms of reaching an age at which he might now 
rightfully assert his prerogative. The clear implication was that Richard himself acknowledged that he had not been sufficiently 'mature' to conduct the affairs of state before his twenty-first birthday.

So a discussion on the minority of Richard II is in one sense an historical anomaly since one of the underlying problems of Richard's reign was that there was no minority as such. The word 'minority' was never used in official documentation. It is significant in this respect that the councils set up in the first years of Richard's reign to supervise his government were not called minority but 'continual' councils, though this fact has not stopped historians from using the term to describe the period when they were in operation. ${ }^{20}$ The word 'minority' assumes a set of formal circumstances which were not in existence in these years and which most contemporaries would have struggled to recognise or accept. It also suggests a 'neatness' to the arrangements put into place to meet the challenge of Richard's youth when it was precisely the lack of definition and the absence of overall direction which characterised the young king's gradual assimilation of political power. It is, then, these very early years of Richard's reign which require careful re-examination, for these were the years in which the underlying tone of politics for at least the first half of Richard's reign, up until 1389, were to be defined. The period was once famously dismissed by Anthony Steel as 'dreary in the extreme'. ${ }^{21}$ On the contrary, these years hold a particular fascination for the way in which the political community chose to respond to the particular challenges presented by the rule of a boy-king. The early years of Richard II's reign have been considered more favourably in more recent work, not least in the excellent narratives of the reign by Tuck and Saul, but whereas the emphasis of this work has tended to focus more generally on the basic question >'how successful was the minority government of Richard II?'< there are a number of subsidiary issues that would repay more detailed scrutiny. Where exactly did power and authority reside in the early years of Richard's reign? To what extent, if at all, did Richard partake in government from the very beginning of his 
rule? If limitations were placed on Richard's authority, were they imposed on him or did they reflect genuine deficiencies in the king's ability to discharge his kingly duties or indeed, like Henry VI, ${ }^{22}$ a reluctance by the king to take on the full gamut of responsibilities that went with his office? Exactly what role did that key political personality of the period, John of Gaunt, play in these years? These questions provide the bedrock for the following discussion, but they also draw us into deeper concerns about the nature of late medieval kingship and its capacity to cope with minority rule. Above all, they invite a more general consideration as to whether we characterise the period in terms of 'crisis management' or whether we should credit the system of monarchical government with the capacity to cope quite satisfactorily with the advent of a boy king.

\section{2. 'Minority' Government: $\mathbf{1 3 7 7 - 8 0}$}

\subsection{The Continual Councils}

In retrospect it would be easy to say that what should have happened in 1377 was for John of Gaunt, in his position as the most senior royal prince and Steward of England, to have headed a regency or protectorate government that would not only have provided clear political leadership, but also a critical line of demarcation separating the period of Richard's royal 'apprenticeship', when he was learning the ropes of what being king entailed, and the start of his rule proper when a formal and public declaration of his majority rule might have closed down the potential for political dissent on the grounds that the king still needed supervision. ${ }^{23}$ But in the absence of any formal prescription as to what should happen in the event of a boy king acceding to the throne, the arrangements put into place in 1377 were determined above all by the politics of the moment and in this sense the appointment of continual councils between 1377-80, instead of a regency, 
made every sense. As is widely acknowledged, a general mistrust of Gaunt's motives made a regency government an impractical and potentially dangerous proposition. Gaunt was a highly controversial figure: he was widely associated with the discredited regime which had been attacked in the Good Parliament of 1376, and his heavy-handed and vindictive treatment of the Londoners in the Autumn of that year, and the first months of 1377, hardly instilled confidence in his ability to exercise authority in an even-handed and judicious manner. ${ }^{24}$ His apparent championing of the religious dissenter John Wyclif in the Summer of 1377 had also generated a strong residue of ill-feeling towards him from within the Church. ${ }^{25}$ What the kingdom needed above all in 1377 was the restoration of a semblance of political equilibrium and the most practical means of achieving this was to institute some form representative government in which all possible political interests were served - that is to say a government, so to speak, of 'national unity'. The expedient of collective government had already been attempted in the Good Parliament when a continual council had been installed at the request of the Commons. ${ }^{26}$ Although short-lived, it provided an obvious model to tackle and to some extent neutralise the challenges faced by a fractured and unsettled political community at the outset of Richard II's rule. $^{27}$

Table: the membership of the continual councils, drawing on N. B. Lewis, "The "Continual Council" in the Early Years of Richard II, 1377-80', EHR 41 (1926), 246-51 (an asterix indicates appointment on more than one occasion):

July-Oct 1377

Earl of March*

Earl of Arundel*

Courtenay, bishop of London*

Erghum, bishop of Salisbury*

William Lord Latimer

John Lord Cobham

Sir Richard Stafford*

Sir John Deveraux*

Sir Hugh Segrave*

Sir Roger Beauchamp*

Sir John Knyvet*

Sir Ralph Ferrers

\section{Oct 1377-Oct 1378}

Earl of March*

Earl of Stafford

Courtenay, bishop of London* Erghum, bishop of Salisbury* Appelby, bishop of Carlisle Sir Richard Stafford* Sir John Deveraux* Sir Hugh Segrave* Sir Henry Scrope Sir John Knyvet*

\section{Oct 1378-Jan 1380}

Earl of Arundel*

Earl of Suffolk

Wykeham, bishop of Winchester Harewell, bishop of Bath and Wells Sir Roger Beauchamp* Sir Aubrey de Vere Sir Robert Rous 
For understandable reasons, the continual councils have attracted considerable interest in scholarship and have consequently come to be regarded, in a sense, as the defining characteristic of royal government in Richard's early years. Particular attention has been given by historians to the political profile of the members of the council in order to demonstrate the lengths to which the political community went to ensure that they were inclusive and truly representative. ${ }^{28} \mathrm{We}$ certainly cannot ignore the divisions and tensions which existed within the political community, and the concomitant need to produce a politically balanced body of men, but to regard the continual councils only in these terms risks oversimplifying the political dynamics of the day by reducing the factors which governed the interaction of the council's members - and their patrons - to the rather inflexible straightjacket of faction and partisanship. There is a danger in assuming that the council members were wholly preoccupied with what had happened in the past, during the turbulent last years of Edward III's reign, when in fact it was the problems and challenges presented by the succession of a boy-king at a very difficult juncture in the war against France which must have featured uppermost in their minds. Similarly, when scrutinising the membership of these councils, we should countenance the possibility that the experience and competence of the individuals chosen, and their willingness to undertake an intensive period of service on behalf of the crown, were factors that were just as important in influencing decisions on appointment as whether they were 'Gaunt's man', a former adherent of the Black Prince or a champion of the constitutional reforms advocated by the Commons in the Good Parliament. There were some exceptionally well-qualified administrators on these councils. Take, for example, William Latimer. The controversy surrounding Latimer's disgrace in the Good Parliament and his later rehabilitation by John of Gaunt should not obscure the fact that this man had been positioned at the very heart of royal government for almost a decade: he had been steward of the household between 1368 and 1370, and acted as chamberlain between October 1371 and 1376. He had also been appointed constable of Dover castle and was warden 
of the Cinque ports from 1372, and had been utilised on several critical diplomatic missions in the early 1370s. ${ }^{29}$ Similarly, Sir John Knyvet, who was appointed twice, could claim to be one of the leading statesmen of his time: he had been a chief justice of the king's bench since 1365 and had been chancellor for no fewer than four and a half years between 1372 and $1377 .{ }^{30}$ William Wykeham, bishop of Winchester brought a similar level of expertise and experience to the third continual council of 1378: from 1361 he had acted a royal secretary; from 1363 he was a royal councillor and from this year until 1367 he had been keeper of the privy seal; from 1367 until 1371 he had served as chancellor and throughout the early 1370s had continued acting as a key member of the king's council. ${ }^{31}$ Even the comparatively obscure figure of John Harewell, bishop of Bath and Wells had served as constable of Bordeaux and later chancellor of Gascony for much of the 1360s.

The appointments to the continual councils need not just been seen in terms of the administrative aptitude of the personnel; they contained an equally rich seam of military service and experience. Again, such considerations have tended to be obscured by the concentration on factional politics so that, for example, the appointment of men closely allied to the Black Prince has generally only been seen in terms of the counterbalance they represented to Gaunt and his followers. In fact, the selection of men who had formerly served the Black Prince meant, almost by default, that the councils could draw on an extensive and invaluable body of military know-how which may have featured as strongly as political and administrative credentials in determining the choice of appointment. It should be remembered that the AngloFrench truce expired only three days after Edward III died on 21 June 1377, and this was followed very soon afterwards by French attacks on the south coast of England, Calais and Aquitaine ${ }^{32}$ this, together with a rapidly deteriorating situation on the Scottish borders, placed a special premium on the ability of the councils to respond to the military threats which England now faced. In fact, a close scrutiny of the personnel appointed to the continual councils suggests 
that they were intended to be as much 'war' councils as 'administrative' councils: John Lord Cobham, for example, served in France in 1359-60, 1366-7 and 1369, and had been on the embassy which had negotiated the Anglo-French truce of $1375 ;{ }^{33}$ Sir Richard Stafford had been in the vanguard of the Crécy campaign in 1346, he was present at the siege of Calais in the same year and had been rewarded for his 'good service' in the Poitiers campaign of $1356 ;{ }^{34}$ Sir John Devereux had taken part in the Black Prince's Nájera campaign of 1367, he was appointed seneschal of La Rochelle and the Limousin in 1370, and of Saintonge in 1372 and had served as captain of Brest in the same year; ${ }^{35}$ Sir Ralph Ferrers was at the siege of Calais, he was present at Poitiers in 1356, in 1358 he had been appointed as captain of Calais and Guines and in 1370 had been admiral of the fleet which had taken Sir Robert Knolle's army to France; ${ }^{36}$ and Sir John Segrave was noted by Froissart as participating in the ill-fated expedition of 1373 which had aimed to re-conquer those parts of Gascony which had been overrun by the French. ${ }^{37}$ Both Henry Scrope and William Latimer, as well as Sir Robert Hales, had begun their careers as soldiers. ${ }^{38}$ Even the appointment of Thomas Appleby, bishop of Carlisle, to the continual council of October 1377 would appear to have been underscored by military considerations: Appleby had been actively involved in border affairs for over a decade as one of the wardens of the west march (he had first been appointed in 1367). ${ }^{39}$ His experience and knowledge of the AngloScottish conflict would have proved particularly valuable in the Autumn of 1377 a few months after a major cross-border offensive launched by George Dunbar, earl of March, heralded a new period of increased Anglo-Scottish hostility. ${ }^{40}$

In political terms, the councils undoubtedly achieved an admirable degree of inclusiveness and consequently they projected a very strong sense of political cohesion and administrative order. But this, in a sense, was one of their main purposes. The minority councils were the 'public face' of government during the period. Their membership was announced in parliament, their terms of reference were defined in parliament and their lifespan was determined 
by parliamentary sessions. They exuded an air of regularity, stability and transparency: above all, a sense of well-being and reassurance that government was in capable and reliable hands. The councils did not, however, constitute the sum total of government in these years and we should certainly not regard them as a real substitute for the royal prerogative. At least from the point of view of the Commons, the members of the council appointed in October 1377 were 'to be continually at hand to advise on matters concerning the king and kingdom with the king's officers', and to oversee the expenditure of the 'money granted them for the wars'. ${ }^{41}$ The close working association of the council's members with the 'king's officers' is particularly noticeable and suggests a close affiliation to what, in circumstances when the king was an adult, we might describe as the king's 'administrative' council. ${ }^{42}$ This is an important distinction, for in identifying the locus of power and authority in Richard's early years it is necessary to understand that this was an age of bureaucratic monarchy in which a large volume business transacted in the king's name would actually have been delegated to his principal ministers. ${ }^{43}$ Many of the matters discharged by the continual councils of Richard's early years would therefore have been no different in kind or importance to the matters considered independently by royal councils at other times. Indeed, evidence of warranty notes issued by the council or by the king and council on letters patent in the first years of Richard II's reign suggests that the volume of business which the continual councils discharged in the course of their existence (i.e. 1377-80) was not noticeably higher than in later periods when the king's council was operating under less formal or prescribed conditions (see Figures 1 and 2). The period of continual council 'rule' may not therefore have represented such a radical departure from the norms of royal government and administration in other periods. It might then be that the primary motivation of the Commons in having the councils convened with a fixed 'aristocratic' membership was to ensure an adequate level of supervision over the actions and decisions of the king's principal officers - the chancellor, treasurer and keeper of the privy seal. ${ }^{44}$ Membership of the council would 
undoubtedly have been a mark of status, but the responsibilities were onerous and the condition attached to appointment, that $r e$-appointment should not occur within two years, though this was ignored in many cases, derived as much from a concern to 'protect' councillors from further imposition as to ensure that government was not monopolised by a limited group of men. ${ }^{45}$

In assessing the record of the continual council we must therefore recognise that its remit was fairly limited. For sure, it fulfilled a vital role in discharging large volumes of administration, but in terms of policy making we must look elsewhere to identify the political initiative. Thus, when Saul sums up the record of 'minority' government under Richard II as 'lacking either clarity of vision or efficiency of policy-making', this judgement cannot be made simply on the basis of the workings and nature of the continual councils: it has to be seen in light of government in general during the early years of Richard's reign. ${ }^{46}$ Crucially, if we are looking for the locus of power and authority in these early years, for the forum where the really important decisions were taken, we must countenance a system of government that was far less structured or prescribed than the appointment and operation of the continual councils alone suggests. We ought also to envisage a method of decision-making that was far less open to public scrutiny than the very public swearing in of the continual council in parliament intimated. This point is demonstrated by the reluctance of the Lords in October 1377 to agree to the second of the Commons' requests to divulge the identity of 'those who will accompany the person of our same lord the king' $\cdot{ }^{47}$ The request was turned down on the grounds that 'it seemed to them [i.e. the Lords] too burdensome and difficult to place anyone about their lord the king who did not wholly please him': ${ }^{48}$ there was a keen sense in which the arrangements surrounding the 'governance' of the king himself were to be decided behind closed doors. The response also highlighted the paradoxical position of the king himself: that is to say, that on the one hand, the way in which government was to function during Richard's early years was the subject of 
political debate within parliament, in recognition of his youth and inexperience, but on the other hand, a line was drawn on the extent to which the domestic circumstances of the king was to be considered 'public' property, on the basis that the king himself possessed the ability and discernment to choose his own counsellors and advisors.

If we regard the continual councils in rather less exalted terms than their prominence in the records would suggest we must clearly look elsewhere to obtain a complete picture of where power and authority lay in these years. This is not a straightforward exercise. It was in very nature of the decision to maintain the notion that Richard was himself the source of political authority at this time that the official records of government usually hid the true origins of a decision or instruction by noting that it had been initiated by the king. Officially, the king ruled England in these years: his counsellors and advisors merely facilitated his will. On the surface at least the English polity was very successful in maintaining the fiction that Edward III had been succeeded by a fully mature adult king. But if we investigate more closely it becomes apparent that the continual councils were but a single string in many-stringed bow, and that the functions which its members performed were by no means the decisive factor in shaping the nature and dynamics of politics in these years.

\subsection{The Great Council}

First then, the Great Council, so-called because of its size and the high political standing of its members. ${ }^{49}$ The period $1377-80$ witnessed one of the most intensive periods of activity by this type of enlarged and reinforced royal council in the later Middle Ages. The meetings of the Great Councils were not routinely recorded; their existence, at least in this period, is indicated by the survival of formal summonses, by occasional references in chronicles or official records and by the existence of warranty notes recording that an instrument of government had been authorised 
'by the Great Council'. The warranty notes deserve special mention because it is in this period that an unprecedented number of letters issued on authority of the 'Great Council' can be found in the chancery rolls. As Figure 3 demonstrates, a spectacular surge occurred in the middle months of 1378 when a total of 424 and 80 such warranty notes were recorded in the patent rolls of March and May respectively. ${ }^{50}$ This was a level of administrative activity that surpassed all normal measures and suggests that a Great Council, or several meetings of this body, had been convened to clear a large backlog of business which had built up since the beginning of the reign. In fact, a closer investigation of the sort of matters which were discharged by the Great Council in these months shows that the vast majority were letters of 'inspeximus and confirmation' which in essence validated annuities or offices which had been granted in the reign of Edward III. Inevitably the greater proportion of such grants were issued to men who held office in government or who discharged some function within the royal household. ${ }^{51}$ Typical of the recipients of such letters were: Master John Bray, physician of the late king; Gilbert del Spitel, groom of the ewry of the household; John Fastolf, a king's esquire; Robert Appelby, serjeant-at-arms; and John Gosebourn, one of the auditors of the Exchequer. ${ }^{52}$ It is not known what part, if any, these individuals were expected to play in securing their annuities, but it is possible, given the shear volume, that the process was undertaken more for auditing purposes than to consider in detail the particular merits of individual cases. Long lists of confirmations were drawn up in the course of the Great Council meeting. On 9 March 1378, for example, at least thirty confirmations were recorded; ${ }^{53}$ on 11 March the number exceeded forty; ${ }^{54}$ and on 23 March there were at least fifty cases. ${ }^{55}$ The fact that these confirmations were attributed to a body described as a 'Great Council' is important, because whether or not large numbers of bishops and nobles turned up to witness these ratifications - unfortunately no evidence exists to shed light on this point - it is clear that great value was placed on the broad consensus which usage of the term 'Great Council' could bring to important decisions on crown expenditure. The 
other effect of having such a large number of confirmations recorded in the chancery rolls and broadcast as letters patent throughout the kingdom was no doubt to emphasise the continuity which existed between the old and new reigns. It may well be that the accession of Richard II saw a resurgence in the fortunes of men associated with the Black Prince, ${ }^{56}$ but in terms of sheer numbers of personnel who served and surrounded the king, Richard's regime - that is to say his 'establishment' - would have borne great similarity to his grandfather's.

The warranty notes are an important source for conciliar activity, but they have limitations and cannot be relied upon as a definitive guide showing when Great Councils had convened. We know that a Great Council met in February 1379, for example, shortly before the parliament of April in that year, and yet no warranty notes recording the activity of the Great Council were noted in the chancery rolls between December 1378 and May 1379. The Westminster Chronicle also noted that 'on the 5 August [1378] the king held at Reading a council to which all the leading men of the country were summoned, ${ }^{57}$ and Walsingham recorded a meeting of an enlarged council at Windsor between 13 and 16 September (though he does not use the term 'Great Council' to describe it). ${ }^{58}$ Again, there is very little 'administrative' imprint from these meetings in the records of government. Instead, they appear to have been convened to address key matters of policy. It was in a meeting of the Great Council in July 1377, for example, which decided on the arrangements for Richard's early years, including the key decision that a continual council would be installed instead of a regency. ${ }^{59}$ The meeting of February 1379 is especially worth noting in this regard, for it had been convened to consider the perilous military situation which the kingdom now faced, partly it seems because the parliament of 1378 had failed to implement appropriate measures in this regard, and partly because the members of the continual council felt themselves to be insufficiently qualified to address these threats themselves. ${ }^{60}$ The Great Council put into place measures to ensure the defence of the realm ${ }^{61}$ and, as a stop gap measure, it secured loans from a broad cross-section of the political 
community to pay for the military expenditure. ${ }^{62}$ It did not have the power to raise taxation, however, and so it was at this meeting that the decision was taken to call the parliament which met a few months later in April. The Great Council meeting of September 1378 is also likely to have played an important role in determining the parliamentary agenda. It met amidst the controversy surrounding the infamous murder of Robert Hawley in Westminster Abbey and it was almost certainly here that the crown's strategy was devised in meeting the outrage of the bishops and Londoners over the incident.

We do not know who attended the meetings designated as 'Great Councils' between $1377-80 .^{63}$ There was no clear contemporary definition on what was needed to make a 'normal' meeting of the council into a 'Great Council', and it was probably the case that the latter was defined in rather opaque terms as a meeting which was attracted an unusually larger gathering of the kingdom's political elite. The enlarged council meeting of 1379 was reported by Richard le Scrope to have been attended by 'almost all the prelates, abbots as well as others, dukes, earls, barons, bannerets and other wise men of the kingdom', but no further details are known. ${ }^{64}$ Scrope did, however, say that 'all the lords there present voluntarily lent our lord the king various great sums of money'. If the subsequent lists of lenders are any guide, the meeting of the Great Council was attended by the bishops of Chichester, Exeter, Bath and Wells, Winchester, Rochester and Salisbury; the earls of Northumberland, Warwick, Suffolk, Angos, Arundel and the duke of Lancaster; and a further twenty-one abbots and thirteen priors. ${ }^{65}$ Of the less formal meetings, the endorsements of two petitions presented in February 1381, in which the lords of the council were named, may offer important clues about the first years of the reign: John of Gaunt; William Wykeham, bishop of Winchester; Edmund Langley, earl of Cambridge; Richard, earl of Arundel; William, earl of Suffolk; Hugh, earl of Stafford; and Henry Percy, earl of Northumberland were named in both documents; Simon Sudbury, archbishop of Canterbury; William Courtenay, bishop of London and Thomas Brantingham, bishop of Exeter were 
additionally named in one. ${ }^{66}$ It is particularly interesting to see the presence of Gaunt, Langley, Percy and Sudbury in these councils - individuals who were not appointed as permanent members of any of the three continual councils of $1377-80$. It is a reasonable assumption to make that these individuals would also have attended council meetings in the first three years of the reign, and the presence of one or more of them at such gatherings may have been sufficient for the recording clerk to designate the meeting as a 'Great Council'.

\subsection{Parliament}

In the hierarchy of council meetings, the Great Council obviously took precedence over the continual council, but the Great Council was no substitute for a meeting of parliament which was attended, in theory at least, by every member of the noble and ecclesiastical elites, as well as representatives drawn from urban and gentry communities throughout the kingdom. Although parliament was in session for only a relatively short amount of time in the period 1377-80, its influence on the politics and the government of the realm was all-pervasive. This was because the shape and direction of policy was to a great extent dependent on the ready supply of public money, which in turn could only be accessed with the approval of the Commons in parliament. The hold which the Commons had on the nation's purse strings was sufficient in itself to ensure that the representatives would have a key role to play in Richard's early years, especially as war against France was in full swing and the crown was in desperate need of taxation. But by 1377 the Commons had additionally developed over the course of fifty years into a political force of impressive maturity, with a deep understanding of the problems and workings of central government and an innate conviction in their right to question policy and to point out areas that needed attention. ${ }^{67}$ Only a year before Richard's coronation, in the Good Parliament of 1376, the Commons had demonstrated a remarkable capacity to mount a sustained and concerted political 
assault on a group of unpopular courtiers, as a result of which the government had been forced to capitulate almost totally to their demands for reform. ${ }^{68}$ The reforms may have been quickly quashed, but there can be no doubting the profound impact which the Good Parliament had in consolidating the Commons as a political force to be reckoned with. In general, the MPs of the late fourteenth century were respectful of their political superiors and they were acutely aware of their position as bystanders in the business of actually running the government. But this did not make them subservient or obsequious. This much is indicated in the caution exercised by the Lords in 1378 when MPs had requested that five or six of their number might join the Commons to discuss the 'charge' given to them by the chancellor. The Lords rejected the request and suggested instead that a smaller delegation from each house meet separately to 'consult with one another in an informal manner, without trouble, clamour or disturbance' ${ }^{69}$ The exchange provides a rare insight into the dynamics of parliamentary debating in the late fourteenth century and confirms the impression that MPs were outspoken, opinionated and very probably bad tempered in their discussions with each other and with members of the Upper House.

It should come as no surprise, then, to find that the Commons took a very close interest in the arrangements for Richard's 'minority' government. Almost the very first points of business recorded in the opening parliament of the reign were the following three demands relating to these arrangements: firstly, that the names of the eight continual councillors should be openly declared in parliament; secondly, that those surrounding the king should be identified, and assurances given that they would be 'the most virtuous, honest, and worthy of the kingdom' and, additionally, that the royal household would be 'governed with decent moderation'; and thirdly, that the laws of the land should be upheld, with a particular demand that no law should be repealed without parliament. ${ }^{70}$ The second of the requests is particularly significant, for it shows a real sense of proprietorship over the person of the king: the Commons were assuming for themselves the responsibility of ensuring that Richard's early years in power were correctly 
and appropriately administered. It was no doubt because Richard had not officially been declared a minor that the Commons felt compelled to justify their interference in such matters by pointing out what was obvious to everybody: that he was 'at present so innocent and tender in age'. ${ }^{71}$ By asserting themselves as custodians of the king's welfare the Commons were giving practical expression to a fundamental principle underpinning medieval kingship: namely, that the king was seen to personify the realm and that his person was consequently regarded as persona publica.$^{72}$ In other words, because the private life of a king had such a profound effect on the public life of the kingdom, it was perfectly legitimate for the political community to voice its concerns over the arrangements put into place to help the king during his impressionable youth, because from the welfare of the king sprang the welfare of the kingdom.

If we see the crown, and the person of the king, in this way - in essence as 'public property' ${ }^{73}$ - this makes better sense of the rather presumptive attitude displayed by the Commons in their scrutiny of the king's private living arrangements. We should see their disclaimer at the end of their list of demands, that these ought not to be considered derogatory to the 'regality and dignity of our aforesaid lord the king', ${ }^{74}$ to be further indication of the ambiguity attached to Richard's position and the fact that their enquiries sat very uneasily with the king's 'official' status as a fully functioning adult king. But practicalities ruled the day, and no doubt because Richard was considered incapable of effectively expressing the royal will the Commons felt able to raise these concerns. To this, of course, we must add the more practical and enduring factor, that questions relating to the conduct and disposition of the government, including the royal household, often turned on questions about finance and expenditure, areas in which the Commons felt fully entitled to expect co-operation given the strict conditions which were attached to the grants of taxation they provided for the crown's use. ${ }^{75}$ These considerations thus provide context for the Commons' demands for assurances about royal expenditure and about the people surrounding the king. It explains, for example, why the Commons insisted on 
the appointment of war treasurers in October 1377 to make proper accounts of government spending; ${ }^{76}$ and why, in 1379 , a highly intrusive inquiry was made into the king's estate and his revenues, which included the inspection of fees paid to royal officials and of the annuities granted by the king and his grandfather, as well as a wholesale examination of household expenditure. ${ }^{77}$ In a period when the king was considered incapable of bringing the discretion and wisdom imbued in his office to the implementation of royal government the Commons' aim was to make parliament substitute for the king in guaranteeing the good and proper conduct of his officials: in effect, they were not to be accountable to the king, but to parliament, and in particular to the Commons. Perhaps the clearest expression of this agenda was the MPs' demand in 1377 that 'until [Richard] reaches the age to distinguish good from evil', all the chief councillors and officers of government 'might be appointed and provided by parliament' and that any appointment of a chief minister between parliaments ought to be done only by the Great Council and in any case it should be a provisional appointment until ratification in the next assembly. ${ }^{78}$ Although the demands were met only partially, ${ }^{79}$ they demonstrate most emphatically how the Commons were claiming for themselves the right to participate in decisions which would fundamentally shape the course and direction of government in these years.

The circumstances of Richard's non-age, like the dotage of his grandfather, had the effect of significantly increasing the political profile of MPs. It is no accident that in these very years private petitioners began to address their complaints to the members of the Lower House in the hope that their intervention with the king and Lords might secure a favourable response. ${ }^{80}$ This was a measure of the influence they were now considered to hold within the English polity. But we should be cautious in overstating the power which the Commons could wield. They might attach conditions to the grants they made in parliament or insist on careful and prudent royal spending, but the Commons did not have the ability to ensure that their demands 
were met. Some of their requests were not even agreed to. We have just seen how their request for the 'public' appointment of the key officers of state in parliament was fudged, and it is worth remembering the short shrift given to their demand to have the identity of those surrounding the king revealed. ${ }^{81}$ The attempt of the Commons in October 1377 to revive the agenda of the Good Parliament in October 1377, by having its ordinances confirmed by statute, were also dismissed peremptorily, in spite of the fact that the wool subsidy from that assembly - which the crown was still collecting - had been granted explicitly on this understanding. ${ }^{82}$ Even the continual council was rather less the creature of the Commons than we might expect: the councillors were chosen only by the Lords, and at least in 1377 , they were sworn to office in front of the Lords only. In 1379, parliament had ended before all the continual councillors had been chosen. The fact is that the Commons were first and foremost political lobbyists and whilst they could undoubtedly bring great pressure to bear on the crown by the hold they enjoyed over the supply of taxation, their powers - even at this high point in their political profile - remained limited.

To address the subject in this way, however, runs the risk of characterising the political dynamics of parliament solely in terms of a trial of strength between MPs and peers. Undoubtedly there were disagreements, seemingly stemming in large part from the Commons' inaccurate appraisal of the crown's financial situation, ${ }^{83}$ but the prevailing mood at this time was determined above all by the imperative to maintain political consensus and stability. In 1377 a ten year old boy had succeeded to the throne at a point when the fortunes of war had decisively turned against England and when, in the domestic political scene, serious fissures existed just beneath the surface. For many, the kingdom must have appeared very close to the brink of utter destruction. ${ }^{84}$ In these circumstances differences of opinion or clashes over policy will always have been tempered by the need to retain a common sense of unity and purpose. Even over an issue as close to the Commons' heart as crown income and expenditure, we cannot assume that the political community was neatly divided along parliamentary lines into those (the Commons) 
who wanted the crown to account for its spending and those (the Lords) who cared little for such matters. It is interesting, in this regard, to note how the Commons couched their request in October 1377, where they asked for the repeal of all gifts 'granted in deceit of our lord the king [Edward III]', in terms of saving the 'estate of our most honoured lords the sons of our lord [king] ... who are of poor standing ... [so that they may be] suitably relieved by some of the said gifts' ${ }^{85}$ Petitions for financial recompense presented by Thomas Woodstock and other peers of the realm in the early years of Richard II's reign are a useful reminder that an insolvent crown frittering away public money was in nobody's interests (except, possibly, the small clique who benefitted from the king's largesse). ${ }^{86}$ Indeed, the point can be made more forcefully in light of the great state loan of March 1379 when a wide range of the king's subjects pledged sums of money to finance the kingdom's defence ahead of an anticipated parliamentary subsidy. ${ }^{87}$ The amounts loaned to the crown ranged from $£ 100$ (mainly earls and some bishops) to 5 marks; London, which was listed separately, raised a staggering $£ 5,000 .{ }^{88}$ The loan would certainly have intensified a common desire to ensure prudent government expenditure, but it is interesting to speculate that it would also have generated a significant lobby group within the Commons in favour of parliamentary taxation, so that the loans would be adequately paid off. The dubious methods by which the loan had apparently been solicited by members of the royal household might additionally explain why the Commons and Lords were prepared to countenance such an invasive inquiry into household costs later that year. ${ }^{89}$

For the officials, nobles and ecclesiastics who either represented or acted for the crown during Richard's early years, the need to maintain political consensus in parliament was borne not simply out of the need to retain the Commons' favour so that they would grant taxation; it went to the very heart of what furnished their actions with legitimacy and authority. Royal power was predicated on the notion that the king's right to rule over his subjects derived from the representative qualities inherent in his office. ${ }^{90}$ Without a king ruling effectively, 
parliament provided the most obvious mechanism to generate an alternative source of representational legitimacy by imbuing the actions of the king's agents with the assent and endorsement of the Commons. The government of Richard's early years was thus not 'forced' into acting through parliament but rather saw the institution as a way of engendering a sense of collective responsibility and therefore support for its actions. It listened to, and frequently acted on, the demands of the Commons because not to have done so would have made a mockery of the claim central to its existence that it stood and acted for the common interest. It was this basic principle which explains the rather undignified way in which Gaunt made an issue out of the rumours which had been circulating in 1377 about his intentions towards the throne. ${ }^{91}$ This was not just about wounded pride or offended ego; it was absolutely critical, if Gaunt was to command any authority in the coming months and years, that he not only asserted himself to be acting in the common interest, but that he had the explicit acceptance of the Commons that this was indeed the case. It also explains, at least partly, ${ }^{92}$ why it fell to the Commons to bring to an end the system of continual councils in 1380 because without the support of MPs, the councillors had no consensus on which to base their authority.

\subsection{John of Gaunt}

Gaunt's role in the infamous Hawley/Shakel affair highlights the central position that he occupied in government at the time. The outlines of this episode are well known. ${ }^{93}$ Shortly after Richard's accession, Robert Hawley and John Shakell had defied the wishes of the council by refusing to reduce the ransom of the count of Denia, who had been captured at the battle of Nájera in 1367. For their contumacy they had been imprisoned in the Tower of London in October 1377, but in August 1378 they escaped and claimed sanctuary in Westminster Abbey. ${ }^{94}$ Sir Alan Buxhill, acting on the instructions of the council, then attempted to have the pair 
arrested and in the ensuing scuffle within the abbey Hawley and a sacristan were cut down and killed. It was almost certainly as a result of the outrage caused by this violation of sanctuary that the decision was taken to hold parliament at Gloucester rather than Westminster. Gaunt was actually overseas - or 'on the high seas' - at the time of the murders, but this did not stop contemporary chroniclers holding the duke responsible for the outrage. To some extent these sentiments are understandable because Gaunt would almost certainly have been at the very forefront of the defence mounted by the crown against the abbot of Westminster's accusations in the Gloucester parliament. Walsingham's account of Gaunt's return from his expedition, when he attended a council meeting at Windsor, is highly instructive on the matter. When the duke heard that William Courtenay, bishop of London had pronounced sentence of excommunication on all those who had been involved in the affair, in spite of royal letters ordering him to desist from such action, Gaunt was reported to be 'very angry; and he said that he was particularly outraged at the impudence of the [bishop] who ... had scorned the royal requests and persisted in [his] obstinacy'. ${ }^{95}$ Gaunt was apparently even more furious at the fact that when the bishop 'had been invited by the king to attend the council, he had arrogantly scorned the invitation' ${ }^{96}$ If the account is accurate, it shows how Gaunt had assumed the role of spokesman for the king and, by implication, how royal policy was being determined or directed by the duke. His angry reaction to the contempt shown by the bishop paralleled very closely the vigorous and aggressive assertion of royal dignity that was later to be displayed in parliament.

This leads to a series of more general points about Gaunt's role and position in the first years of Richard's rule. In the first place, we should, once and for all, scotch any notion that Gaunt was either snubbed in 1377 when the arrangements for Richard's 'minority' were fixed or that his political ambitions and his authority were in some way curtailed in the early years of the reign by the combined forces of an unreasonably suspicious political community. ${ }^{97}$ Walsingham's famous remark, that Gaunt elected to 'retire from the court' following the 
coronation, can too easily be regarded as an act of pique by a nobleman who failed to achieve what he most desired: the position of regent. ${ }^{98}$ The word 'retire' suggests defeat, resignation and failure - which well suited Walsingham's jaundiced view of the duke and his actions. ${ }^{99}$ But Gaunt's standing in the realm was in practice not much different early in Richard II's reign than at the end of Edward III's reign. It is true that he was not made regent, but there is no evidence to show that this is what he desired. Indeed, we cannot be sure that the possibility of a regency was seriously considered in 1377 : it is entirely possible that the sentiments articulated fifty years later in 1427, that a regency represented an accroachment of royal power, already formed the common currency of political thought in the last quarter of the fourteenth century. ${ }^{100}$ In this respect we must remember that Gaunt was nothing if not a staunch upholder of the royal prerogative. Besides, Gaunt was astute enough politically to appreciate that a more flexible system of government, in which he could direct royal policy by speaking 'through' the king, was much more likely to bring him control and acceptance than a regency government in which the lines of authority were more clearly delineated - in other words, where the blame for failed policies could be laid more squarely on his shoulders and where there was consequently much greater scope for dissent. ${ }^{101}$ Ironically, the more straightforward direction of a regency government would probably have better served the interests of a distrustful political community than the ambiguous system of government installed in 1377 which enabled Gaunt to influence his young nephew for the most part without any element of accountability. ${ }^{102}$

Aside from political considerations, a regency style government may not have suited the 'hands-on' approach of Gaunt to the external threats facing the realm at this point: the energy with which he engaged in campaigning against the French and Scots in the late 1370s suggests that his primary interest lay in military pursuits rather than the day-to-day running of government. He, incidentally, would not have been alone in holding this view: it should be remembered that the Great Council of February 1379 had originally been intended to meet the 
previous month, but the plans had changed because 'the prelates and lords excused themselves from attending; some of them saying that because of important and urgent matters which they had to attend to elsewhere, namely both the business of the kingdom as well as their own affairs, they were not able to come to nor stay at the said council, and especially so soon after the long labour they had undertaken at the said parliament of Gloucester.' ${ }^{103}$ Gaunt's modern biographer has portrayed him as remote and politically isolated, a man who found it hard - or was disinclined - to forge close political alliances or friendships and who devoted his interests and energies to fulfilling his own goals rather than those of the realm. ${ }^{104}$ We should not dismiss the possibility that it was Gaunt's lack of appetite for regency, rather than the obstacles put in his way by a distrustful political community, which best accounts for the decision to creative an alternative form of government in 1377.

It has been argued that the 'denial' to Gaunt of the regency highlighted the limitations of his power, ${ }^{105}$ but it is equally possible to regard the less prescribed position he occupied in government in the late 1370s as an affirmation of his political ascendancy: he did not need to be made a regent, or to hold any other official 'minority' title, in order to be recognised and treated as the premier nobleman of the kingdom whose opinion carried more weight than anyone else's. ${ }^{106}$ His position as the senior royal prince, as the largest landholder in the kingdom besides the king, as Steward of England and as a king of a foreign land (i.e. Castile) assured him undisputed political pre-eminence at this time. The fact that only he appears to have been personally summoned to attend council meetings provides a measure of the importance attached to his opinion and suggests that important decisions on policy could not be reached without his involvement. ${ }^{107}$ Within council meetings themselves it was Gaunt who appears to have assumed leadership. Again, we rely on Walsingham for elucidation on this point. According to the chronicler, during the meeting of the Great Council early in the Autumn of 1378 Gaunt had taken control of the subsidy which had been granted in the parliament of October 1377 insisting that he 
would determine how it was to be spent to ensure the proper and effective defence of the realm. If Walsingham is to be believed, Gaunt did not enjoy the wholehearted support of his fellow lords yet none felt confident enough to challenge his authority: '[t]he nobles, although unwillingly, agreed to this importunate request with, it is said, some bitterness of heart. They already knew that fortune was against them and that the duke held such power in the kingdom that it was extremely inadvisable for them to go against his wishes'. ${ }^{108}$ Though no doubt induced by the particular circumstances of Gaunt's declaration of loyalty to the king, the Commons' affirmation of the duke in October 1377 as their 'their chief aid, comforter, and counsellor in this parliament' - that is to say, the most important of the lords who they had nominated to be part of an intercommuning committee - most certainly reflected the reality that Gaunt, as the chief political figure within parliament, was best placed to convey the crown's needs to the assembled MPs. ${ }^{109}$ The point is worth emphasising, for it underlines an important difference between popularity and respect. Gaunt was not popular; but he commanded respect and authority within the polity by virtue of his power and proximity to the crown. In light of the actions of the Bad Parliament of January 1377, which rolled back the reforms implemented by MPs in the Good Parliament six months earlier, we may even question how far he was the politically isolated figure as commonly depicted in contemporary and modern writing. Walsingham was at such a loss to explain the drastic voltre face of January 1377 that he assumed - quite erroneously as it turned out - that Gaunt had packed the assembly with his own supporters. ${ }^{110}$ The chronicler was quite unable to contemplate the possibility that not everyone shared his harsh views of the duke, and that within the broader political community outside London there may have been a sizeable body of opinion which actually identified its interests with the nobleman. ${ }^{11}$

To a point, Gaunt's dominion within the polity is affirmed by the role ascribed to him, and his younger brothers, in the opening parliament of the reign: they were not expected to attend council meetings on a regular basis, but it was stressed that if 'any dispute by 
maintenance in the country or elsewhere' arise between council members, the latter should suffer grievous penalty 'the cognizance and jurisdiction over which matters shall belong to the king himself, and his uncles of Spain, Cambridge, and Buckingham'. ${ }^{112}$ This was explicit confirmation of the political pecking order: Gaunt, with his brothers as deputies, was positioned at the very top of the scale, albeit below the king himself. More importantly, they were being accorded exclusive rights to exercise the sort of power of arbitration and judgement normally reserved for the king alone. ${ }^{113}$ This was quite an explicit affirmation of their position of proximity to the king and, by implication, their removal or detachment from the rest of the political community. No doubt it was in recognition of the particular and extensive powers which Gaunt possessed as the most senior statesman of the realm that petitioners often chose to address their supplications to him, rather than to the king or council, in the first years of the reign: there was no question in their minds as to where ultimate authority lay. ${ }^{114}$ So, it should be clear that the issue of whether or not a regency government should be installed related more to the structure of government than to questions about the location of power and authority within it. Gaunt's seniority meant that he did not have to be physically present at Westminster to ensure his central position in the running of the kingdom's affairs: a combination of his political stature and the placing of his friends and allies in key positions of responsibility (in particular, Richard le Scrope as chancellor ${ }^{115}$ and Guichard d'Angle, earl of Huntingdon, as tutor to the king between 1377 to $1380^{116}$ ) meant that he retained a very tight and comprehensive grip on government in these years. It was arguably these positions in government, rather than who was appointed to the continual council, which determined the real locus of power in these years. Technically Gaunt was not regent, but in reality this was what he was. It was this reality which probably explains why a number of contemporary writers were in doubt as to real power lay in these early years (indeed one chronicler, albeit a French writer, thought that a regency had indeed been installed). ${ }^{117}$ 


\subsection{The King: Grace and Favour}

We come then to the final piece in the jigsaw: the king himself, and the extent of his involvement in government from the very beginning of his rule. It is a question which has never received detailed scrutiny, quite possibly because it is so hard to decipher from the records how far decisions recorded in the name of the king actually reflected the king's active participation. ${ }^{118}$ In the absence of explicit consideration the tendency is perhaps to assume that Richard had very little hand in the running of government for the first years of the reign. ${ }^{119}$ No doubt the stories of Richard having to take a nap midway through the proceedings of his coronation, and his being carried through the crowds on the shoulders of Simon Burley, have contributed to the impression that Richard would have been far too young to have any real impact on government at this time. ${ }^{120}$ And yet, we cannot dismiss Richard as a political non-entity. The fiction of Richard's majority rule remained a fiction insofar as he did not discharge the full gamut of responsibilities and duties which might be expected of an adult king. This is rather different to saying that he took no active part in government at all. For contemporaries, these early years of the reign were probably conceived in terms of an apprenticeship in which it was felt desirable to expose Richard as much as possible to the demands of kingship whilst reserving for institutions like the continual council, Great Council and parliament the main administrative burden and important decisions on policy and expenditure. The Commons' demands in 1377 to be given assurances about the arrangements for Richard's governance suggests that he was regarded as capable of exercising a sufficient level of discretion as to be a cause for concern. The Lords sought to reassure MPs by stating that 'the knights, squires, and all about the king, should be restrained on pain of grievous penalties ... from seeking anything from the king on their own behalf, or on behalf of others,

which could in any way be charged to the king or kingdom'. ${ }^{121}$ The assumption was that Richard 
had the power to grant favour to those courtiers who surrounded him, but that he did not have the experience or wisdom to be able to refuse such requests if they made demands on royal revenues or on income derived from taxation.

In the notes of warranty attached to chancery instruments there are clear signs of the king's involvement in a variety of different decisions, though it must be stressed that the number of such occasions where his participation can be established beyond doubt, are relatively few. ${ }^{122}$ In the very first months of the reign, before a continual council had been formally constituted and apparently while a privy seal was being made, ${ }^{123}$ it can be seen in Figure 4 that there was a very brief period in which the signet seal - the surest indication of the personal involvement of the king in a decision - was used to authorise letters issued under the Great Seal. In June 1377, for example, a signet letter was sent from the royal manor of Kennington to chancery ordering the appointment of Richard Story as keeper and surveyor of lordships in parts of Wales; ${ }^{124}$ in July, a signet letter authorised the appointment of John May to buy stone and timber for repairs to the manor of Langley in Hertfordshire; ${ }^{125}$ and another, in the same month, charged Walter Hanlee, a king's serjeant-at-arms, and John Clerc to organise ships and mariners to serve the king for six weeks. ${ }^{126}$ In the following months and years, the appearance amongst the chancery records of the warranty note 'by king and council' or 'by king and Great Council' ${ }^{127}$ shows that Richard attended council meetings on a fairly regular basis and was presumably consulted directly on those matters which had been authorised in his and the council's name. In early 1378 a large number of chancery instruments authorised in this way related to the confirmation of grants or annuities which individuals had received in the reign of Richard's grandfather. ${ }^{128}$

Whilst other warranty notes such as 'by council', 'by Great Council' or 'by petition of parliament' indicated very straightforwardly that the king had not been involved in decisions taken within government, the same cannot be said of the warranty note 'by privy seal' 
which, as Figure 5 demonstrates, was easily the most ubiquitous of chancery authorisations used in this period. Although the privy seal could be mobilised by either the council or the king, detailed investigation into its use in the reign of Henry IV has shown that more often than not it was used by the king in preference to sending letters direct to the chancellor using his signet seal. ${ }^{129}$ This was a more formal or solemn method of validating a royal mandate and might well have been most suitable for the circumstances of Richard early years in power when he was spending much of his time travelling between royal manors and palaces in the Thames valley. ${ }^{130}$ The great difficulty is that privy seal instruments disguise their true origins, so whilst it is perfectly possible that large numbers of writs were sent to the chancellor by the keeper of the privy seal at the behest of the council, it is equally possible that a good proportion emanated by royal order, more likely than not as a result of a signed bill or signet letter which the king had sent to the keeper for action. ${ }^{131}$ The point is demonstrated by the fact that the keeper of the privy seal, John Fordham, appears to have divided his time in the first six months of the reign between Westminster and the itinerant royal court, for there are a large number of chancery instruments which were noted as having being authorised by privy seal letters issued at one of the king's Homes Counties' manors. ${ }^{132}$ The clear implication is that on these occasions the privy seal had been mobilised directly within the context of the royal court. At other times when the privy seal was removed from the presence of the king, we have only the letters of the signet seal to indicate what lay behind a privy seal letter. Unfortunately, the destruction of the greater part of the privy seal archive in the seventeenth century, which housed these written instructions, means that we will never be able to recover an accurate picture of the what lay behind the warranty note 'by privy seal', but we should at least countenance the possibility that Richard was involved in a considerable proportion of privy seal letters issued in these early years of his reign.

Some extant petitions dating to the period 1377-80 would appear to confirm that Richard was actively involved decisions affecting the welfare and circumstances of his subjects. 
Some examples, it is true, we must take at face value if we are to sustain such a conclusion, though it is doubtful in this context that decisions recorded in the king's name would have been rendered such without the king having been consulted in any way at all. To the petition presented in 1377 by the merchants of York, for instance, which made complaint against a group of Scottish merchants who had robbed the petitioners and suggested two ways of bringing the miscreants to justice, the endorsement read 'the king wills the second option'. ${ }^{133}$ Another petition presented from York in 1377 - this time from Richard de Ravenser master of St Leonard's Hospital who asked for the confirmation his hospital's charters - was answered: 'The king wishes this well as it is of royal foundation'; ${ }^{134}$ and the response to a petition from Adam Ramsey, who asked for office and wages, was 'This bill was granted by the king'. ${ }^{135}$ In other cases we are on surer ground in concluding that Richard had personally considered the contents of a supplication. It is surely of some significance that the petition presented by William Windsor and Alice Perrers, against the judgements brought against Perrers in the parliament of October 1377 , was initially brought before the king. ${ }^{136}$ True, we learn from the endorsement that Richard subsequently sent the bill to his council, presumably because it related to such a sensitive political issue, but the fact that he had received it first shows that at least some contemporaries regarded it as worthwhile to send their requests directly to the boy king. This point borne out by the fact that from the very start of the reign many supplications were addressed to the king alone. ${ }^{137}$ An even more emphatic indication of Richard's capacity to deal with questions of patronage - or royal grace - in his own right is the endorsement to the petition of John de Cobham, who requested confirmation of the agreement he had reached with Edward III whereby the crown would inherit Cobham's estates upon his death. ${ }^{138}$ In the endorsement a clerk had specified that the petition was 'For the king', and the full response noted that the 'king wills that the said bishop of Lincoln and Guy de Bryan ... be diligently examined' on the matter. The explicit reservation of the petition for the attention of the king is highly significant, for it 
clearly shows the importance that was attached to having the king's involvement in questions relating to the royal patrimony. An equally persuasive indication of Richard's active role in these early years is provided by the endorsement to a petition presented in the parliament of 1378 by John Blaunchard who asked to be repossessed of a bailiwick in the forest of Grovely (Wilts.) which had been unjustly seized into the king's hands. ${ }^{139}$ It was ordained that Blaunchard was 'to have a letter of the privy seal of procedendo, provided that they do not proceed to give judgement without consulting the king'. The case was to be decided in chancery, but only after the king had been directly consulted on the matter.

In all these cases, it should be stressed that the mention of the king in the endorsements to these petitions does not indicate that the king was handling the cases in isolation. What they do suggest, however, is that the arrangements put into place for government in the first years of Richard II's reign were multi-layered, and that alongside the more obvious 'institutional' contexts, such as the council or parliament, in which the business of government was discharged, there also existed a more informal and much less clearly defined or prescribed context - the royal household would perhaps be the least contentious term to describe it - in which matters were referred to the king who reached decisions in consultation with the men and women who immediately surrounded him - the familiars of his chamber and household. That policy could emanate independently from the royal household, even in these early years, is amply demonstrated by the controversy surrounding the Leybourne inheritance in which the king and his advisors chose to ignore the advice of parliament, and presumably also the wishes of John of Gaunt, by wilfully obstructing the fulfilment of all the terms attached to Edward III's will (Gaunt was one of the executors of this will). ${ }^{140}$ In the parliament held at Gloucester in 1378 the executors of Edward III's will made complaint that the receiver appointed to administer the Leybourne lands had been prevented from making payment out of the issues 'by certain of the council of our lord the present king', who had ordained that payments could not be made 
'without special mandate from the king'. Crucially, the king had not provided this mandate. ${ }^{141}$ The carefully worded grievance is interesting for its oblique reference to the king's 'councillors' - or counsellors. Almost certainly this did not mean the councillors appointed to attend the continual council, but rather the less easily identifiable individuals who surrounded the king and inhabited his court. The episode provides a striking illustration of the weight of authority which the court could already bring to bear over legal and governmental processes when policy was directly advocated by the king or in his name. It also highlights, in rather ironic terms, how much more freedom of action Richard enjoyed during his years of 'minority' in comparison to the period between 1386 and 1388 when power was all but taken away from him by parliament and the Appellants.

The identity of the king's counsellors is hard to pin down, but for the early years of Richard's rule they almost certainly would have included some of the men who had served with the Black Prince and who now filled important positions in the royal household. Sir Simon Burley, as the king's vice-chamberlain, is an obvious individual to cite; but there were others, such as William Packington, keeper of the wardrobe, Alan Stokes, keeper of the great wardrobe, Richard le Scrope, steward of the household (until March 1378) and his successor, Sir Hugh Segrave, Robert Braybrooke, king's secretary, and John Fordham, keeper of the signet seal. ${ }^{142}$ Aubrey de Vere would also have held a key position in Richard's household as the royal chamberlain; and the appointment of the royal knight Sir Robert Rous (along with de Vere) to the third continual council to represents 'court' interests suggests that he too was prominent. ${ }^{143}$ In his role as the king's tutor, Guichard d'Angle, earl of Huntingdon, would presumably also have had an important influence on the young king, as would Sir Richard Abberbury, a chamber knight, who also served briefly in this capacity. Over a dozen more chamber knights were serving the king in his early years and these were for the most part either former members of the Black Prince's retinue or former servants of Edward III. ${ }^{144}$ Nor should we forget the very 
considerable influence which Richard's mother, Princess Joan of Kent, probably played in guiding him in these early years. It was, after all, Princess Joan who had engineered the reconciliation between John of Gaunt and the Londoners in February 1377, and it was she, with Simon Burley, who was absolutely central in the early negotiations for Richard's marriage. ${ }^{145}$ Princess Joan had been present with the king in London during the Peasants' Revolt of 1381 and, according to Anonimalle chronicle she had actually accompanied her son to the meeting with the rebels at Mile End. ${ }^{146}$ At least one petitioner, the prior of Coventry, felt she possessed sufficient authority to warrant inclusion with the council in the opening address of a petition presented at some point early in the reign against the men of the same city. ${ }^{147}$

\section{Richard's Assumption of Power}

If, as I have argued in the previous section, the incidence of privy seal writs in the years 1377-80 provides some measure of the volume of activity which Richard II engaged in from the very beginning of his reign, this helps put into perspective the decision by the Commons to insist on the abandonment of the continual councils in 1380 , since it is clear that the activity of these counsellors accounted for only a proportion of the business of government discharged at this time. It underscores the points that the counsellors were not absolutely vital to the proper running of government; that the Commons were probably justified in seeing their role in 'helping' Richard govern as increasingly unnecessary and irrelevant; and that the decision was driven as much by economic reasons (i.e. by the high wages paid to the councillors) as by an underlying unease at the incompatibility of an 'artificially' constituted council with the free exercise of the royal will. ${ }^{148}$ It also highlights the point that the abandonment of the councils did not mark any significant change in the underlying form of government, between a period in which the king did little and a period when the king suddenly found himself at the centre of things. The ending of 
the continual councils indicated a reconfiguration of the framework of government, not a fundamental change in the nature of the authority which Richard was exercising. ${ }^{149}$ As one recent commentator has pointed out, the very fact that the continual councils were abandoned must surely indicate that Richard had already, by 1380, proved his abilities and his willingness to 'undertake at least some of the functions of an adult ruler' ${ }^{150}$ Without a formally declared majority, however, the process by which Richard came to be seen, and came to see himself, as a fully functioning adult king could never be clear cut. In later years, as we have seen, this became a useful political weapon for the king's opponents to justify their impositions on Richard's authority, but in the comparatively benign years of the early 1380s this uncertainty fuelled a desire in contemporaries to place great store by events or episodes which appeared to show that Richard had at last matured sufficiently to be able to rule the kingdom effectively in his own right. For example, Richard's role in the Peasants' Revolt of 1381, in which he apparently met the rebels face-to-face, subdued them and then single-handedly led them away from London, became a major cause célèbre amongst the chroniclers of the day, Walsingham in particular seeking to contrast the decisive leadership of the king with the incompetence and cowardice of his useless courtiers. ${ }^{151}$ This was the first time in the reign that contemporary writers had given Richard a real personality, with an important and positive influence on the events of the day. Richard's fourteenth birthday in January 1381, which marked a transition from pueritia to adolescentia - the point at which, according to canon law, a child entered adulthood - was a happy co-incidence which no doubt encouraged contemporary writers to emphasise Richard's part in dealing with the rebellion later in the Summer. ${ }^{152}$ Richard's marriage to Anne of Bohemia in January 1382 was another clear 'rite of passage' for the young king and was given great significance by the political community, though the failure of the union to produce offspring obviously greatly diminished its value for Richard as a way of shoring up political support. ${ }^{153}$ Recent discussion has also argued that Richard himself sought to assert his adulthood in both 
symbolic and practical terms by consistently pressing parliament between 1381 and 1386 to fund royal expeditions to the continent. ${ }^{154}$ The proposal was continually frustrated by the lack of adequate funding until, in 1385, Richard was able to lead an army in person to Scotland.

There are other signs that Richard was taking control of his destiny. In the past, great store was placed on the notable increase in the recorded use of the king's signet seal at the end of 1383 to authorise the dispatch of letters under the privy or Great Seals (see Figure 4). The sudden prominence of the signet seal appeared to indicate that it was only now that Richard began taking on the responsibilities of government, and it also neatly fitted the idea that Richard was somehow predisposed to exercise his authority in a wilful and 'unconstitutional' way, because instructions sent to the chancellor on the authority of the signet seal avoided the safeguards provided by the privy seal office as intermediary between the king and chancery. ${ }^{155}$ In its fundamentals, this interpretation can be dismissed, for the use of the signet seal almost certainly marked a change in bureaucratic procedure rather than a significant change in the level of Richard's participation in government. But as Saul has argued, for the change to have occurred in the first place, suggests a greater application of Richard to the government of his realm. ${ }^{156}$ This was, in other words, the first sign that Richard was shaping government to suit his needs: it did not mark the invidious erosion of accountability in government, simply a more efficient and streamlined mechanism of conveying instructions from the king to his chancellor. It may also be significant that about this point petitions bearing the name of the king's chamberlains begin to appear in the archives. These were the supplications which had been presented to the king in his chamber and which, at least if later examples are any guide, were normally sent to the privy seal office to have a writ sent into chancery. The existence of these 'chamberlain's bills' in files which had once pertained to chancery suggests that these endorsed bills, like the signet letters, were now being sent direct to the chancellor for action instead of via the privy seal. Again, we should not necessarily read anything sinister into this new procedure. 
They are, however, an excellent guide to show how much influence men such Simon Burley and Robert de Vere were having on the young king. ${ }^{157}$

Of all the incidents in these years which demonstrated Richard's desire to assert his independence from the supervision and close monitoring which had characterised his early years, it was the dismissal of his chancellor Richard le Scrope in July 1382 which is arguably the most illuminating. Scrope had made a stand over the king's apparently irresponsible distribution of the manors and lordships which pertained to the inheritance of the earldom of March. ${ }^{158}$ According to Walsingham, who was writing some time after the event, Scrope 'openly refused [these] requests, asserting that the king was weighed down by much debt from various quarters'. ${ }^{159}$ Scrope was said to have been motivated out of a concern to protect the royal patrimony from the youthful exuberance of the boy king: 'he [Scrope] had no intention of issuing any confirmatory charters ... made by the king, who had not yet passed his years of boyhood, lest, perhaps, he might himself suffer the king's ingratitude later on'. Walsingham, never one to hold back on voicing his direct opinion, wholeheartedly agreed with the need for this action, stating that Richard 'being but a boy, did not hesitate, and granted what they [the foreigners of the court] requested'. The chronicler then went on to describe how, on hearing of his chancellor's obduracy, the king 'who had only the wisdom of a boy ... in a spirit of anger ... sent men to demand the seal from [Scrope]', and moreover that, 'nobody dared to say anything openly about the matter, for fear of incurring the ill-will of the king's attendants, and because of the unreasoning youthfulness of the king himself'. This was the first time Walsingham was openly critical of the king, and the first time responsibility for failure was laid squarely on the king's own shoulders. We are left in doubt as to Walsingham's explanation for the crisis: in the space of two short paragraphs he alluded to the king's immaturity - his 'boyhood' - on no fewer than four occasions. 
We may question how much embellishment Walsingham used in this account, but there is no disputing the fact that Scrope was peremptorily dismissed or that the chancellor's office remained vacant for over two months. ${ }^{160}$ It is this dismissal, of course, which holds significance for the present discussion, but it is also worth remarking on the extraordinary actions of the chancellor who had categorically refused to carry out the wishes of his sovereign. This provides a very clear insight into prevailing attitudes towards Richard II even after the minority councils had been abandoned, and of the very real sense in which the king continued to be viewed as holding a position in the polity which permitted the sort of paternalistic restraint which Scrope appears to have tried to impose. Richard was old enough to be allowed some freedom in the way he governed and in the choice of personnel he surrounded himself with, but he had not yet achieved the stature and position which protected his decisions and actions from the harsh censure and opposition of his critics. Whether or not the chancellor was justified in making this stand, it is perfectly apparent how this attitude, and specifically Scrope's actions in the summer of 1382, would have infuriated the king and driven him to the outer limits of total frustration. His dismissal of Scrope was an extraordinarily bold act. It was the clearest assertion a king could make that government served his needs, and that crown officials were there to be appointed - or dismissed - as he saw fit. Richard was not going to let a major practical consideration in the effective running of government stand in the way of his desire to assert the principle that the chancery, and chancellor, should be instruments of his will. In terms of government, this act signified Richard's coming of age.

The delay in finding an alternative to Scrope points to the fact that the decision to remove him had not been pre-planned. Possibly it had not even been thought through, though it should be remembered that a recent precedent had been set just a year previously when the regime had coped without a chancellor for over eight weeks after the execution of Archbishop Sudbury at the height of the Peasants' Revolt. As in the summer of 1381, so too in the summer of 
1382, government did not grind to a halt. This is demonstrated in Figure 6 which shows the number of letters patent which were authorised by the king in person. ${ }^{161}$ Indeed, it is evident from a strongly worded signet letter addressed to his treasurer, keeper of the privy seal and keeper of the chancery rolls that Richard was monitoring very closely what they were doing and had high expectations that in discharging their duties the king's interests above all else should be served. The letter, dated to 26 August 1382, 'expressed surprise that they who for a time have the keeping of the great seal have taken upon them to present John Scarle clerk of the chancery to the church of Newton Regis in Worcestershire, as if they had the power of the chancellor [whereas] the king has presented John Menhir chaplain of the household'. ${ }^{162}$ It went on to say that they 'should make no presentation in future without the king's special command'. This was the clearest statement yet of Richard's desire to exercise control over the distribution of patronage: if the chancellor was not available to do this for him, he would do the job himself. The episode shows very clearly the emerging personality of Richard II, as a strongly independent and authoritative young king.

\section{Conclusion}

The paper has thus ended by providing a glimpse into the political turbulence of Richard's later years. The political community had been very anxious to see their king emerge from his youth from his 'unofficial' minority - and assume full powers as a fully functioning adult king presiding over a peaceful and politically inclusive kingdom. Instead, what they got was a king who was headstrong and non-compliant, and who seemed to favour a small group of individuals who had no natural claim to be the king's foremost advisors and counsellors. The problem was not that Richard was reluctant to take on the reins of government, ${ }^{163}$ but that Richard was exercising his authority in a way which caused increasing disquiet amongst an important section 
of the political elite. The abandonment of the formal apparatus of 'minority government' meant that power was more clearly and unambiguously focussed on the person of the king and those whom he chose to surround himself with. It was perhaps only natural that Richard gravitated towards individuals such as Robert de Vere, earl of Oxford, Hugh earl of Stafford and Thomas Mowbray, earl of Nottingham who were of his own generation or men such as Simon Burley or Michael de la Pole whose position in the polity was made primarily on the back of service to him rather than to his father or grandfather. Thus, almost as soon as the continual councils had been disbanded, the political community sought new ways of imposing checks and balances on the king's actions, as if the unofficial minority had been given a new lease of life to allow for the continuing deficiencies which the king was perceived to have. In the very parliament (November 1380) which appeared to signal the end of the period of caretaker government by discontinuing the continual councils, a new set of impositions were made on the king in the form of demands for a major enquiry 'to survey and examine in all the courts and places of the king, both in his household as well as elsewhere, the state of the said household, and the expenses and receipts whatsoever incurred by any of his ministers' ${ }^{164}$ The Commons also asked to have the five principal officers of state 'elected and chosen' in parliament, and shortly after the assembly ended Sir John Cobham was appointed to oversee the workings of the household. ${ }^{165}$ It was a pattern that was repeated the following year: several months after Richard had apparently led the kingdom from the brink of disaster by leading the rebels of Essex away from London in June 1382, parliament demanded yet another household commission and imposed another two 'guardians' on the king (the earl of Arundel and Michael de la Pole) to 'accompany the person of the king, and belong to his household, to advise and govern his person, et cetera'. ${ }^{166}$ The fiction of Richard's adulthood had thus given way to the fiction of his youth, or at least an assertion that it was the king's youthful tendencies which disqualified him from taking on the full reins of government. We should remember that in France, throughout the 1380s, 
Charles VI - a king of comparable age to Richard II - was ruling with the aid of a much more formally constituted minority government, so the measures taken by parliament to rein Richard in during this decade would not have appeared to have been unduly repressive or inappropriate. $^{167}$

Patronage, finance and counsel were the issues which defined the conflicts of the late 1380s, but the origins of this conflict arguably lay in the first years of the reign when the political community had become conditioned into thinking that interference with, and management of, a king with adult status was a natural and acceptable state of affairs. The idea that the first years of Richard's reign created the conditions that would later lead to a catastrophic breakdown in political consensus is not, of course a new or obscure one, but whereas previous scholarship has tended to see this historical causation in terms of personalities - of the king, his advisors and his opponents - this discussion points to failings of a more structural kind, in the way government was calibrated at the very outset of the reign. The underlying problem lay in the ambiguity attached to Richard's position, which generated a sense of uncertainty and suspicion, an absence of clear and decisive leadership, and a set of conflicting political imperatives. The situation is amply demonstrated by the contradictions inherent in the actions of the rebels in 1381 . On the one hand, they self-consciously proclaimed their right to take up arms in the belief that Richard, as a young and innocent child, was defenceless against the machinations of his evil counsellors; on the other hand, they looked to Richard - by seeking interviews and presenting petitions to him - to provide the leadership and direction necessary to resolve the kingdom's woes and save their own fortunes. ${ }^{168}$ Richard was a child or an adult depending on particular political needs and circumstances. The political community was thus paralysed in a state of uncertainty as to how to deal with the young king - power was given to him with one hand, in the belief that he was old enough to rule in his own right and that it was in the kingdom's best interests that he did so, only for it to be taken away by the other hand, in the 
belief that he was not quite competent enough to be trusted to exercise full and untrammelled authority, and that it was in the kingdom's best interests to impose safeguards to limit or monitor his exercise of power. The ambiguity surrounding Richard's status would have been increased by the fact that from the very start the king seems to have been exposed to the workings of government and may even have been directly and actively involved in discharging large volumes of government business in person. The matter of governing the realm had thus originally been conceived as a power-sharing exercise. With no formal end to this situation it was perhaps inevitable that Richard would never be allowed the breathing space to develop the political selfassurance and trust which were prerequisites to successful rule. Far from unifying the realm, Richard's acquisition of power exacerbated existing tensions and created new and deep-running fault lines within a political community that had become used to asserting a claim to active participation in politics and government.

It would be easy to judge these years harshly. If contemporaries believed that youth was inherently incompatible with successful kingship, because a boy-king could not exercise 'independent will', why did the political community not face the reality and formally install a minority government? In practical terms, at least, the answer may be found by questioning whether in fact there was any alternative system of government that was obviously better than the constitutional 'fudge' of the early years of Richard II's reign. From 1380, Englishmen need only have looked across the channel to France to see how the appointment of a regent and a formal minority government created a whole set of different, and potentially far more divisive, political problems. ${ }^{169}$ The constitutional settlement of October 1377 was built upon an impressive foundation of political unity because it was focussed upon the person of the king; installation of a regency would have created clearer demarcation, in terms of delineating exactly where real authority lay, but it would have been far less effective in covering over political divisions and dissent would consequently have been much more likely. This leads us to 
an important principle which informed political thinking at the time; namely, that there was no proper alternative to personal kingship, and that maintaining the façade of the king ruling in his own right was infinitely more attractive than an officially declared minority which had dubious claims to political legitimacy and representation. It is telling that there was no contemporary comment on the merits or otherwise of the decision to tackle Richard's youth in this way: the scant attention paid to government in the first years of the reign focussed specifically on the performance and cost of the continual councils rather than on the more underlying issue of where power was or should be located. ${ }^{170}$ It was universally accepted that all authority ought in theory, if not in practice, emanate from the king. Only the king could effectively represent and exercise the public authority with which his office was imbued. In itself this approach to Richard's nonage was a success; the 'minority' years were notable for the high level of 'consensus politics' that was achieved. The difficultly lay in navigating a clear and acceptable path from this position, where a large measure of authority was exercised on Richard's behalf, to a position where Richard was exercising full authority in his own right, and in this respect the English polity singularly failed.

\section{Select Bibliography}

\section{key primary sources}

Parliament Rolls of Medieval England, ed. C. Given-Wilson, et al. (Leicester, 2005), CD-version

The St Albans Chronicle: The Chronica Maiora of Thomas Walsingham, I, 1376-1394, ed. and trans., J. Taylor, W. R. Childs and L. Watkiss (Oxford, 2003) 


\section{key secondary Sources}

Bird, R., The Turbulent London of Richard II (1949)

Dodd, G. (ed.), The Reign of Richard II (Stroud, 2000)

Goodman, A., John of Gaunt: the Exercise of Princely Power in Fourteenth-Century Europe (Harlow, 1992)

Goodman, A., and Gillespie, J. L. (eds.), Richard II: The Art of Kingship (Oxford, 1999)

Holmes, G., The Good Parliament (Oxford, 1975)

Tuck, A., Richard II and the English Nobility (London, 1973)

Saul, N., Richard II (London and New Haven, 1997)

Steel, A., Richard II (Cambridge, 1941)

\footnotetext{
* I would like to express my gratitude to Alison McHardy for reading and commenting on an earlier draft of this chapter, and for generously allowing me to consult her sourcebook on the reign of Richard II ahead of publication (The Reign of Richard II, 1377-1397: From Minority to Tyranny, ed. A. K. McHardy (Manchester University Press, forthcoming).

${ }^{1}$ The St Albans Chronicle: The Chronica Maiora of Thomas Walsingham, I, 1376-1394, ed. and trans., J. Taylor, W. R. Childs and L. Watkiss (Oxford, 2003), pp. 689-91. Walsingham was
} 
writing some time after the event, probably in the early 1390s, for which see ibid., pp. xcviixcviii; and G. B. Stow, 'Richard II in Thomas Walsingham's Chroniclers', Speculum 59 (1984), 68-102, pp. 83-4.

${ }^{2}$ For background, see Victoria County History, Suffolk (1975), II, 56-72 (p. 64).

${ }^{3}$ St Albans Chronicle, p. 691. Also cited in Chronicle of Adam Usk, 1377-1421, ed. and trans., C. Given-Wilson (Oxford, 1997), p. 7.

${ }^{4}$ For the idea that Richard's youth informed much of the opposition to his rule, see A. Tuck, Richard II and the English Nobility (London, 1973), pp. 89, 91; M. Bennett, Richard II and the Revolution of 1399 (Stroud, 1999), pp. 20-21, 197-8; C. M. Barron, 'The Reign of Richard II', in M. Jones (ed.), The New Cambridge Medieval History VI: 1300 - c. 1415 (Cambridge, 2000), pp. 297-333 (see esp. p. 311: 'He behaved like a wayward teenager [in the 1380s] and was treated as such'); W. M. Ormrod, 'Coming to Kingship: Boy Kings and the Passage to Power in Fourteenth-Century England', in N. F. McDonald and W. M. Ormrod (eds.), Rites of Passage: Cultures of Transition in the Fourteenth Century (Woodbridge, 2004), pp. 47-8 and, most recently, C. Fletcher, 'Manhood and Politics in the Reign of Richard II', Past and Present 189 (2005), 3-39, pp. 31-9.

${ }^{5}$ The Westminster Chronicle 1381-1394, ed. and trans., L. C. Hector and B. F. Harvey (Oxford, 1982), p. 229. The 'heir' was possibly a reference to Thomas, duke of Gloucester who was believed to have had designs on the throne at this point. See N. Saul, Richard II (London and New Haven, 1997), pp. 189-90.

${ }^{6}$ Westminster Chronicle, p. 271; P[arliament] R[olls] O[f] M[edieval] E[ngland], ed. C. GivenWilson, et al. (Leicester, 2005), CD-version, parliament of 1388, part 3.

${ }^{7}$ PROME, parliament of 1399, item 55.

${ }^{8}$ See for example, Bennett, Richard II, p. 197.

${ }^{9}$ Chronicle of Adam Usk, p. 7. Usk was a member of the committee which determined the grounds for Richard II's deposition and Henry's accession in September 1399.

${ }^{10}$ See discussion by J. Watts, Henry VI and the Politics of Kingship (Cambridge, 1996), p. 27.

${ }^{11}$ Printed in J. H. Harvey, 'The Wilton Diptych: A Re-examination', Archaeologia 98 (1961), 128, pp. 27-8.

${ }^{12}$ A useful summary of the various interpretations of the Diptych is provided by D. Gordon, 'The Wilton Diptych: An Introduction', in D. Gordon, L. Monnas and C. Elam (eds.), The Regal Image of Richard II and the Wilton Diptych (London, 1993), esp. pp. 20-22.

${ }^{13}$ This was the phrase used by the Commons in 1377 to introduce the arrangements they proposed for the king's minority: PROME, parliament of October 1377, item 14.

${ }^{14}$ See, for example, A. Steel, Richard II (Cambridge, 1941), pp. 38-41, 174-5; V. H. Galbraith, 'A New Life of Richard II', History 26 (1942), 223-39, p. 226 (Richard was 'similar to the lonely boy at school ... misunderstood by the masters [and] a misfit in his own class'); Saul, Richard II (the 'effects of his upbringing are likely to have given him a powerful sense of uniqueness while leaving him inexperienced in the handling of relations with the great men of the realm.') - p. 454; A. K. McHardy, 'Richard II: A Personal Portrait', in G. Dodd (ed.), The Reign of Richard II (Stroud, 2000) ('Richard's personality, and the problems which this caused, was formed in his childhood...'), p. 30.

${ }^{15}$ For a welcome note of caution, see G. B. Stow, 'Stubbs, Steel, and Richard II as Insane: The Origin and Evolution of an English Historiographical Myth', Proceedings of the American Philosophical Society 143 (1999), 601-38. I have also benefited from reading an unpublished paper by Dr Brenda Carter, 'Richard II on the Couch: History and Psychology'.

${ }^{16}$ See the recent discussion by W. M. Ormrod who argues that the commission of government set up in 1386, which accrued to itself all executive powers of the king, was justified in the eyes 
of the political community precisely because the king had not yet formally asserted his majority: 'Coming to Kingship: Boy Kings and the Passage to Power in Fourteenth-Century England', in N. F. McDonald and W. M. Ormrod (eds.), Rites of Passage: Cultures of Transition in the Fourteenth Century (Woodbridge, 2004), pp. 31-49, (pp. 47-8).

${ }^{17}$ Westminster Chronicle, pp. 391-3.

${ }^{18}$ J. B. Henneman, Olivier de Clisson and Political Society in France under Charles V and Charles VI (Penn., 1996), pp. 129-30.

${ }^{19}$ The declaration made by Richard to his council was followed by public declarations which did not couch his assertion of authority explicitly in terms of the attainment of majority rule, merely that 'the king has taken upon his own person the governance of the realm, purposing to rule with deliberation of the council more prosperously than heretofore': CCR, 1385-9, p. 671.

${ }^{20}$ See, for example, Saul, Richard II, chapter 3 entitled 'Accession and Minority, 1377-81'.

${ }^{21}$ Steel, Richard II, p. 44.

${ }^{22}$ See J. L. Watts, 'When did Henry VI's Minority End?', in D. J. Clayton, R. G. Davies and P. McNiven (eds.), Trade, Devotion and Governance: Papers in Later Medieval History (Stroud, 1994), pp. 116-39.

${ }^{23}$ See Tuck, Richard II, p. 33.

${ }^{24}$ On the Good Parliament, see G. Holmes, The Good Parliament (Oxford, 1975); G. Dodd, 'A Parliament Full of Rats? Piers Plowman and the Good Parliament of 1376', Historical Research 79 (2006), 21-49, pp. 27-30. On his treatment of London, see R. Bird, The Turbulent London of Richard II (1949), chs 1-2; P. Nightingale, 'Capitalists, Crafts and Constitutional Change in Late $14^{\text {th }}$-Century London', Past and Present 124 (1989), 3-35, esp. pp. 5-24.

${ }^{25}$ J. Dahmus, William Courtenay, Archbishop of Canterbury 1381-1396 (Penn., 1966), chs 3 and 4; A. Goodman, John of Gaunt: the Exercise of Princely Power in Fourteenth-Century Europe (Harlow, 1992), pp. 241-4.

${ }^{26}$ PROME, parliament of 1376, item 10. The names of the councillors are recorded in The Anonimalle Chronicle 1333 to 1381, ed. V. H. Galbraith (Manchester, 1927), p. 91.

${ }^{27}$ Holmes, Good Parliament, pp. 105, 158-9. The council lasted for about three months, between July and October 1376.

${ }^{28}$ Tuck, Richard II, pp. 36-7; Saul, Richard II, pp. 28-31, and for one of the first expressions of this approach to the councils, see T. F. Tout, Chapters in the Administrative History of Medieval England, 6 vols. (Manchester, 1920-33), III, 324.

${ }^{29}$ G. Holmes, 'Latimer, William, fourth Baron Latimer (1330-1381)', Oxford Dictionary of National Biography (Oxford, 2004), Online version.

${ }^{30}$ W. M. Ormrod, 'Knyvet, Sir John (d. 1381)', Oxford Dictionary of National Biography (Oxford, 2004), Online version. There is some uncertainty attached to his role on the council because no records exist of the payment of his wages. However, it is most likely that his remuneration was considered to be covered by the annuity of 200 marks granted to him in January 1377: Lewis, "Continual Council”, p. 248.

${ }^{31}$ P. Partner, 'Wykeham, William (c.1324-1404)', Oxford Dictionary of National Biography (Oxford, 2004), Online version.

${ }^{32}$ Saul, Richard II, pp. 31-34.

${ }^{33}$ R. Allen, 'Cobham, John, third Baron Cobham of Cobham (c.1320-1408)', Oxford Dictionary of National Biography (Oxford, 2004), Online version.

${ }^{34}$ R. Barber, Edward, Prince of Wales and Aquitaine: A Biography of the Black Prince (London, 1978), pp. 50, 76, 153.

${ }^{35}$ D. S. Green, 'The Household and Military Retinue of Edward the Black Prince', Unpublished PhD Thesis, University of Nottingham, 2 vols. (1998), I, pp. 58-9. 
${ }^{36}$ Ibid., p. 65.

${ }^{37}$ Cf. C. J. Rogers, The Wars of Edward III: Sources and Interpretations (Woodbridge, 1999), pp. 198-99.

${ }^{38}$ In October 1365 Hales had participated as a knight of St John in the crusade of Pierre I of Cyprus to capture Alexandria: J. Sarnowsky, 'Hales, Sir Robert (d. 1381)', Oxford Dictionary of National Biography (OUP, 2004), Online version.

${ }^{39}$ R. K. Rose, 'Appleby, Thomas (d. 1395)', Oxford Dictionary of National Biography (OUP, 2004), Online version.

${ }^{40}$ For background, see A. J. MacDonald, Border Bloodshed: Scotland and England at War 1369-1403 (East Lothian, 2000), pp. 45-51.

${ }^{41}$ PROME, parliament of October 1377, item 18.

${ }^{42}$ For discussion, see G. Dodd, 'Henry IV's Council, 1399-1405', in G. Dodd and D. Biggs (eds.), Henry IV: The Establishment of the Regime, 1399-1406 (Woodbridge, 2003), pp. 95-115 (esp. pp. 96, 102-3).

${ }^{43}$ A point most effectively illustrated in the discussion of J. A. Tuck on the powers exercised by the treasurer: 'Richard II's System of Patronage', in F. R. H. Du Boulay and C. M. Barron (eds.), The Reign of Richard II: Essays in Honour of May McKisack (London, 1971), 1-20.

${ }^{44}$ These individuals normally formed the core of the administrative council when it met. In Henry IV's reign it was not unusual for the council to comprise just these officers and one or two of the king's advisors: Dodd, 'Henry IV's Council', p. 105.

${ }^{45}$ For example, see PROME, parliament of October 1377, item 22.

${ }^{46}$ Saul, Richard II, p. 45.

${ }^{47}$ PROME, parliament of October 1377, item 19.

${ }^{48}$ Ibid., item 26.

${ }^{49}$ For a useful discussion of the Great Council in the reign of Richard II, see A. L. Brown, The Governance of Late Medieval England, 1272-1461 (London, 1989), p. 175 and A. Goodman, 'Richard II's Councils', in A. Goodman and J. L. Gillespie (eds.), Richard II: The Art of Kingship (Oxford, 1999), pp. 59-82 (pp. 76-82).

${ }^{50}$ The existence of these warranty notes was recorded by Tout, Administrative History, III, 336, note 5. Tout points out that, 'after the close of the parliament of 1377, there was, for some thirteen months, an almost constant stream of warranties by great council recorded both in the patent and close rolls', and more recently Saul, drawing on Tout's work, has suggested that 'in 1379 meetings of the [Great Council] were held every few weeks' (Richard II, p. 46). Caution should be exercised before linking warranty notes with meetings of the Great Council: there could often be a period of some delay before chancery letters were issued as a result of authorisation by the Great Council so that a spread of warranty notes over an extended period of time may not in fact indicate the semi-continuous existence of this body.

${ }^{51}$ For brief discussion, see C. Given-Wilson, The Royal Household and the King's Affinity: Service, Politics and Finance in England, 1360-1413 (1986, New Haven and London), p. 213. ${ }^{52}$ All these grants are in $C P R, 1377-81$, p. 136.

${ }^{53}$ TNA, C 81/1539/1.

54 TNA, C 81/1539/2.

55 TNA, C 81/1539/4. The other days for which lists survive are: 19 March (TNA, C 81/1539/3a), 26 March (TNA, C 81/1539/7); 10 May (TNA, C 81/1539/11); 30 May (TNA, C 81/1539/12); 9 June (TNA, C 81/1539/9a); 18 June (TNA, C 81/1539/9b).

${ }^{56}$ Saul, Richard II, pp. 28-9, 31.

${ }^{57}$ Westminster Chronicle, pp. 18-21.

${ }^{58}$ St Albans Chronicle, p. 245. 
59 Tuck, Richard II, p. 36.

${ }^{60}$ PROME, parliament of 1379 , item 5.

${ }^{61}$ Commissions of array, 'to resist hostile invasion and the destruction of the English tongue' were issued for Northumberland, Westmorland, Yorkshire; and commissions to 'guard the shores of the sea' and to 'array and equip [men] with arms' were issued in Devon, Kent, Norfolk, Suffolk, Surrey and Sussex: CPR, 1377-81, pp. 359-60.

${ }^{62}$ See below, pp. 000-000.

${ }^{63}$ Possibly the closest we come to identifying the sorts of people who are likely to have attended such meetings lies in a petition presented by the 'Commons of London' in December 1376 in which the names of those attending a meeting of the Great Council, in the 'White Chamber near the Painted Chamber' of Westminster Palace, were provided in the endorsement. The individuals were: John of Gaunt; the archbishops of Canterbury and York; the bishops of London, Durham, Lincoln, Bath and Wells, Worcester, Salisbury and Norwich; the earls of March, Warwick, Stafford, Suffolk and Salisbury; Lords Percy (later to become earl of Northumberland), Neville, Latimer, Basset of Drayton, Fitz Walter; and the chancellor, treasurer, keeper of the privy seal and others. For this and another related petition see TNA, SC 8/ 59/2909 \& 2908; see also CPR, 1374-77, pp. $387 \& 389$.

${ }^{64}$ PROME, parliament of 1379 , item 5.

${ }^{65}$ CPR, 1377-81, pp. 635-8.

66 TNA, SC 8/173/8639, 173/8632.

${ }^{67}$ See G. L. Harriss, King, Parliament and Public Finance in Medieval England to 1369

(Oxford, 1975), pp. 509-17; ibid, 'War and the Emergence of the English Parliament, 12971360', Journal of Medieval History 2 (1976), 35-56.

${ }^{68}$ For an overview of the Good Parliament see Holmes, Good Parliament, and Dodd, 'A Parliament full of rats?'.

${ }^{69}$ PROME, parliament of 1378 , item 23.

${ }^{70}$ PROME, parliament of October 1377, items 18-20.

${ }^{71}$ Ibid., item 17.

${ }^{72}$ See E. H. Kantorowicz, The King's Two Bodies: A Study in Mediaeval Political Theology (Princeton, NJ., 1957), chpts 3-5; and Watts, Henry VI, pp. 22-3.

73 ' $[\mathrm{T}]$ he Crown, being something that concerned all, was not a private but a public inheritance', Kantorowicz, King's Two Bodies, p. 373.

${ }^{74}$ PROME, parliament of October 1377, item 20.

${ }^{75}$ Grants of taxation could only be demanded by the crown if a state of urgent necessity could be shown to exist, and specifically (but not exclusively) if the funds were required for the defence of the realm. The conditional nature of such grants inevitably exposed the crown's subsequent expenditure of this money to public scrutiny. On the principle of necessity, see Harriss, King, Parliament and Public Finance, pp. 33-9; M. Prestwich, English Politics in the Thirteenth Century (Basingstoke, 1990), pp. 114-17.

${ }^{76}$ PROME, parliament of October 1377, item 27.

${ }^{77}$ PROME, parliament of 1379 , item 12.

${ }^{78}$ PROME, parliament of October 1377, item 50.

79 The Commons included the chief justices of both benches, the chief baron of the exchequer, the treasurer of the household, the clerk of the privy seal, and the chief keepers of the forests in their list of officers to be appointed 'by parliament'.. The crown agreed to have only the continual councillors, the chancellor, treasurer, steward of the household and chamberlain nominated by the Lords in the assembly, and it did not explicitly agree to have those appointments made outside parliamentary time ratified within the assembly. 
${ }^{80}$ For discussion, see G. Dodd, Justice and Grace: Private Petitioning and the English Parliament in the Late Middle Ages (Oxford, 2007), pp. 166-71.

${ }^{81}$ PROME, parliament of October 1377, item 26.

${ }^{82}$ PROME, parliament of October 1377, item 56. The regard given to the acts of the Good Parliament was no doubt due to the high level of continuity of personnel between the two assemblies, and above all to the reappointment of Sir Peter de la Mare as Speaker in October 1377. For the re-election of MPs see, N. B. Lewis, 'Re-election to Parliament in the Reign of Richard II', EHR 48 (1933), 364-94.

${ }^{83}$ G. Dodd, 'The Lords, Taxation and the Community of Parliament in the 1370s and 1380s', Parliamentary History 20 (2001), 287-310, pp. 303-4.

${ }^{84}$ An indication of the prevailing sense of national vulnerability is provided by a letter sent in February 1379 by Henry Wakefield, bishop of Worcester to the archdeacon of Gloucester requiring prayers for the king and realm because "the country is surrounded by such terrible enemies that human power is lessened and it is right to ask God's help that the kingdom may be brought by laudable triumph ... to tranquil and happy times, and that the enemy shall not succeed, nor shall the small plant from the royal stem lose his inheritance': A Calendar of the Register of Henry Wakefield, bishop of Worcester 1375-95, ed. W. P. Marett (Leeds, 1972), p. 152. For a broader context to these prayers, see A. K. McHardy, 'The English Clergy and the Hundred Years War', Studies in Church History 20 (1983), 171-8.

${ }^{85}$ PROME, parliament of October 1377, item 48. The poor financial standing of Woodstock is discussed by Tuck, Richard II, pp. 45-6 and A. Goodman, The Loyal Conspiracy: The Lords Appellant under Richard II (London, 1971), pp. 87-94.

${ }^{86}$ On Woodstock, see Dodd, 'Lords, Taxation and Community of Parliament', pp. 301-2. For petitions from other lords, see TNA, SC 8/125/6231 (1380, Edmund Mortimer, earl of March); 125/6220 (1380, John Mowbray, earl of Nottingham); 109/5416 (1381, Thomas Arundel, bishop of Ely); 107/5317 (1377-81, Thomas Hatfield, bishop of Durham). On Gaunt's debts, see A. Goodman, 'John of Gaunt', in W. M. Ormrod (ed.), England in the Fourteenth Century: Proceedings of the 1985 Harlaxton Symposium (Woodbridge, 1984), pp.67-87 (pp. 80-1). ${ }^{87}$ See $C P R, 1377-81$, pp. 635-8.

${ }^{88}$ Ibid., p. 340. London was singled out by Richard le Scrope in his opening address to the 1379 parliament when he reported that the king had pawned the crown jewels as a guarantee against the loans: PROME, parliament of 1379 , item 5.

${ }^{89}$ A common petition presented in 1379 complained that 'various letters of credence under the privy seal were sent to various parts of the realm by certain knights and squires of the king's court, to request loans of silver for the king's use; which letters had blank seal-strips, and the said creditors of their own authority wrote the names of many persons on the seal-strips of the aforesaid letters, and delivered the letters to them, affirming that the king had sent them to them, and they demanded from them sums as great as they wished, and those who excused themselves from paying such sums they fiercely threatened on behalf of the king': PROME, parliament of 1379, item 30. The king's subjects were expected to provide interest free loans to the crown at times of great necessity, but the obligation was qualified by an understanding that the recipients of such requests could set the amount to be loaned themselves and they could excuse themselves on the grounds of poverty. For background, see G. L. Harriss, Aids, Loans and Benevolences', The Historical Journal 6 (1963), 1-19, esp. pp. 6, 12-17.

${ }^{90}$ Watts, Henry VI, pp. 21-31.

${ }^{91}$ PROME, parliament of October 1377, item 14. For the rumours, see St Albans Chronicle, p. 99; and Anonimalle Chronicle, p. 104.

${ }^{92}$ See discussion below, pp. 000-000. 
${ }^{93}$ See Saul, Richard II, pp. 36-8.

${ }^{94}$ The pair presented a joint petition in the parliament of October 1377 asking that four bishops, four earls, four barons and four knights of the council be assigned to hear their right and their evidence 'so that they can come to a suitable decision on the supplicants'. The petition appears not to have been answered: TNA, SC 8/18/895.

${ }^{95}$ St Alban's Chronicle, p. 245.

${ }^{96}$ Ibid.

${ }^{97}$ R. H. Jones, The Royal Policy of Richard II: Absolutism in the Later Middle Ages (Oxford, 1968), pp. 10-11; Steel, Richard II, p. 44; Saul, Richard II, p. 28; Goodman, John of Gaunt, p. 71.

${ }^{98}$ St Alban's Chronicle, p. 157.

${ }^{99}$ Goodman, John of Gaunt, pp. 15-17; St Albans Chronicle, pp. lii-liii, lxxiii, lxxvi-lxxix.

${ }^{100}$ N. H. Nicolas, ed., Proceedings and Ordinances of the Privy Council of England, 7 vols. (London, 1834-7), III, 234.

${ }^{101}$ For the problems which could confront a regency government see D. A. Carpenter, The

Minority of Henry III (London, 1990), esp. pp. 53-4. Note Walsingham's comment that Gaunt's decision to 'retire' from the court in 1377 was informed by his fear that 'if anything bad happened to the king or the realm he would be blamed, and would receive little or no thanks for the good things he had done', St Albans Chronicle, p. 157.

102 For a similar dilemma faced by the political community in discerning (and checking) the influence of the Humphrey, duke of Gloucester on the young Henry VI in the 1430s, see Watts, Henry VI, pp. 117-20, 155-8.

${ }^{103}$ PROME, parliament of 1379 , item 5.

${ }^{104}$ Goodman, 'John of Gaunt', p. 84.

105 Jones, Royal Policy of Richard II, p. 10.

${ }^{106}$ An interesting parallel can be made with the circumstances of 1422 when Humphrey, duke of Gloucester searched in vain to show that Gaunt had been made 'governor of the realm' in order to substantiate his own claims to the title. All that could be found, however, was that 'my lord of Lancastre hadde no such name of gouernor but oonly hadde his bretheren my lord of York and Gloucestre associed to hym for to surveye and correcte the defautes of them that were appointed for to be of the kingis counseil'. See S. B. Chrimes, 'The Pretensions of the duke of Gloucester in 1422', EHR 45 (1930), 101-3.

${ }^{107}$ Cf. Tuck, Richard II, p. 40, note 5.

108 The Chronica Maiora of Thomas Walsingham, 1376-1422, trans. D. Preest and ed. J. G. Clark (Woodbridge, 2005), p. 63.

${ }^{109}$ PROME, parliament of 1377 , item 14.

${ }^{110}$ St Albans Chronicle, pp. 68-71. On the numbers of 'Lancastrians' in parliament, see J.

Wedgwood, 'John of Gaunt and the Packing of Parliament', EHR 45 (1930), 623-5; S. Walker, The Lancastrian Affinity 1361-1399 (Oxford, 1990), p. 239.

${ }^{111}$ For the unhappy relationship between London and Gaunt, see Bird, Turbulent London, esp. pp. 23-8.

112 PROME, parliament of 1377, item 23.

${ }^{113}$ Watts, Henry VI, pp. 21-31.

114 TNA, SC 8/84/4194; 85/4221; 93/4628; 102/5085; 103/5108; 103/5111; 104/5168; 146/7269/ $147 / 7347$.

115 The importance of Scrope to the government of Richard's early years, and his close ties to Gaunt, have been stressed by Saul, Richard II, pp. 50-1. 
${ }^{116}$ For the life and career of this war veteran see J. Sumption, 'Angle, Guichard (IV) d', earl of Huntingdon (c.1308x15-1380)', Oxford Dictionary of National Biography (Oxford University Press, 2004), On-line version. Neither Saul or Tuck ascribe any importance to d'Angle's position in the household, though it is possible that his presence there - and his absence from 1380, after his death - were important factors in shaping the political environment for the king in his early years of rule.

${ }^{117}$ Cf. Goodman, John of Gaunt, p. 71.

118 See, for example, Saul's comment that 'it may only have been from late $1383 \ldots$ that Richard involved himself in routine matters of government', Richard II, p. 110.

${ }^{119}$ See, for example, Steel, Richard II, p. 44: 'The king himself was, of course, too young to affect politics directly for at least four years to come [from his accession]'.

${ }^{120}$ St Albans Chronicle, pp. 152-3; Westminster Chronicle, pp. 414-17.

${ }^{121}$ PROME, parliament of October 1377, item 26.

${ }^{122}$ For an overview of the warranty note, see A. L. Brown, 'The Authorization of Letters Under the Great Seal', BIHR 37 (1964), 125-56.

${ }^{123}$ Saul, Richard II, p. 109.

${ }^{124}$ CPR, 1377-80, p. 6.

${ }^{125}$ CPR, 1377-80, p. 9.

${ }^{126}$ CPR, 1377-80, p. 12.

${ }^{127}$ I.e. 'per ipsum regem et consilium', 'per consilium', 'per petitionem de parliamento'.

${ }^{128}$ For example, see $C P R, 1377-80$, p. 102: confirmation of letters patent dated 12 February 1374 providing John de Surray with an annuity of $£ 100$ for life out of the farm of the city of London (warranted 'by king and council').

${ }^{129}$ Brown, 'Authorization of Letters', pp. 131-40. For further background, see J. F. Baldwin, The King's Council in England During the Middle Ages (Oxford, 1913), p. 257; B. Wilkinson, 'The Chancery', in J. F. Willard and W. A. Morris (eds.), The English Government at Work, 13271336, 3 vols (Cambridge, Mass., 1930-40), I, 179-83; W. M. Ormrod, 'The Origins of the Sub Pena Writ', Historical Research 61 (1988), 11-20.

${ }^{130}$ For Richard's itinerary, see Saul, Richard II, Appendix.

${ }^{131}$ For further discussion on the administrative processes which lay behind the distribution of royal patronage, see G. Dodd, 'Patronage, Petitions and Grace: the "Chamberlains' Bills" of Henry IV's Reign', in G. Dodd and D. Biggs, (eds.), The Reign of Henry IV: Rebellion and Survival, 1403-1413 (Forthcoming, Boydell and Brewer).

132 The following references, dating to 1377, are in CPR, 1377-80: July 20 - Kennington Manor (p. 11); August 2 - Windsor Castle (p. 14); August 19 - Berkhamsted (p. 18); September 21 Bushey Manor (p. 21); October 28 - Shene (p. 34); November 11 - Shene (p. 58).

133 TNA, SC 8/103/5134.

134 TNA, SC 8/184/9180.

135 TNA, SC $8 / 215 / 10731$ (c. 1377 - c. 1378 ).

136 TNA, SC 8/18/891. The bill was also endorsed with the name of Simon Burley, king's tutor and vice-chamberlain, a sure sign that it had initially been considered in the king's chamber; see Dodd, 'Patronage, Petitions and Grace'.

${ }^{137}$ Eg. TNA, SC 8/18/891 (1378); 126/6252 (1377); 184/9180 (1377).

138 TNA, SC 8/18/883 (1377).

139 TNA, SC 8/19/908.

${ }^{140}$ C. Given-Wilson, 'Richard II and his Grandfather's Will', EHR 93 (1978), 320-37.

${ }^{141}$ PROME, parliament of 1379, item 26 (the bill of 1378 was recorded in the parliament roll of 1379). Note Given-Wilson's view that Richard was as much responsible for the controversy 
surrounding Edward III's will as were his favourites, and especially Simon Burley: 'Richard II and Grandfather's Will', p. 334.

${ }^{142}$ Saul, Richard II, pp. 28-9.

143 Tuck, Richard II, pp. 42-3, 48-9.

${ }^{144}$ C. Given-Wilson, The Royal Household and the King's Affinity: Service, Politics and Finance in England 1360-1413 (New Haven and London, 1986), pp. 161-2.

${ }^{145}$ St. Albans Chronicle, p. 93; Saul, Richard II, p. 51. See CPR, 1381-85, pp. 107 and 301

(March 14, 1382 and August 2, 1383) for grants to Burley in recompense for the labour and expense he had gone to in bringing Anne from Germany.

${ }^{146}$ For recent discussion see W. M. Ormrod, 'In Bed with Joan of Kent: The King's Mother and the Peasants' Revolt', in J. Wogan-Browne, R. Voaden, A. Diamond, A. Hutchison, C. Meale and L. Johnson (eds.), Medieval Women: Texts and Contexts in Late Medieval Britain: Essays for Felicity Riddy (Turnhout, 2000), pp. 277-92 (esp. p. 279).

147 TNA, SC 8/209/10448.

${ }^{148} \mathrm{Cf}$. Comment by Walsingham, that the continual councils 'drew from the king's treasury throughout the year a large sum of money, but achieved nothing or very little that was of benefit'; St Alban's Chronicle, p. 345. Note also how the size of the continual councils diminished between 1377-80, from twelve to seven individuals (see Table on p. 000-000). For the constitutional problems caused by such councils, see Watts, 'When did Henry VI's Minority End?', p. 119, and Henry VI, pp. 85-6.

${ }^{149}$ Note, however, that petitions addressed only to the council, very quickly disappeared after 1380. Examples include, TNA SC 8/88/4394; 115/5722; 116/5774; 129/6449; 141/7046; $158 / 7865 ; 159 / 7941 ; 160 / 7982 ; 164 / 8164 ; 165 / 8243 ; 166 / 8273 ; 168 / 8398 ; 170 / 8490 ; 172 / 8587$; 207/10324; 209/10409; 212/10591, 10593; 213/10619, 10647; 215/10715, 10750; 216/10770, $10771 ; 258 / 12867 ; 267 / 13301$.

${ }^{150}$ Ormrod, 'Coming to Kingship', p. 35.

${ }^{151}$ For a summary, see Saul, Richard II, p. 72; W. M. Ormrod, 'The Peasants' Revolt and the Government of England', Journal of British Studies 29 (1990), 1-30, pp. 20-1. Walsingham expressed dismay that not one of the royal knights or esquires who witnessed the humiliation of the Queen Mother in the Tower of London challenged 'a single one of such disgraceful acts', whereas he attributed to Richard 'a resourcefulness and courage beyond his years'; St Albans Chronicle, pp. 425 and 439 (for discussion, see Ormrod, 'In Bed with Joan of Kent', pp. 285-7). The Westminster Chronicle (p. 9) described how 'counsel perished from the wise' at the height of the rebellion, and how London 'was without a clear view of what was to be done'. Richard is then portrayed as an active and clear-header leader boldly declaring to the rebels 'I am you king, your leader, your captain. Those among you who support me are to go out at once into the open country' (pp. 11-13).

${ }^{152}$ N. Orme, From Childhood to Chivalry: The Education of the English Kings and Aristocracy, 1066-1530 (London, 1984), pp. 5-6.

${ }^{153}$ For discussion, see Ormrod, 'Coming to Kingship', pp. 38-9.

${ }^{154}$ Fletcher, 'Manhood and Politics', pp. 31-9. However, Fletcher's contention that Richard's failure to campaign in person on the continent was above all due to restrictions placed on him by a political community reluctant to grant taxation is difficult to reconcile with the account in the Westminster Chronicle of a council meeting held early in 1385 which saw a serious altercation between Gaunt and the other councillors on exactly this topic. Gaunt strongly advocated a French campaign with the French at its head, but he was opposed by all the other councillors apart from his brothers. According to the chronicle, it was as a result of this disagreement that a plot was hatched to murder the duke. From this episode, at least, it is quite plain that the 
reluctance to see the king personally lead an expedition to France emanated from within the court, as it was said that both the king and the 'whole council' felt great displeasure at Gaunt's declaration that he would not assist Richard unless the latter meant to cross the channel:

Westminster Chronicle, pp. 110-13. Richard's reluctance to venture north of the Forth during his Scottish campaign later in the year, in the face of intense pressure from Gaunt, is similarly difficult to reconcile with the idea of a young king desperately keen to prove himself in battle: $S t$ Albans Chronicle, pp. 762-3.

155 The use of the signet seal became a 'political' matter later in the 1380s when the council installed by the Wonderful Parliament of 1386 sought ways of restricting Richard's initiative in government by having royal instructions to the chancellor directed via the privy seal office: Tuck, Richard II, p. 70; W. M. Ormrod, 'Government by Commission: the Continual Council of 1386 and English Royal Administration', Peritia 10 (1996), 303-21, esp. pp. 317-18.

${ }^{156}$ Saul, Richard II, p. 110. I agree with Saul that too much 'politics' can be read into the use of the signet seal, but the argument that its use was specifically the result of a new policy initiated by John Bacon, royal secretary, is less easy to sustain in light of the fact that his appointment occurred a full year before the signet seal came into use. I also disagree that the routine nature of the correspondence authorised by the signet seal meant that 'it could hardly have arisen directly from the exercise of the king's will': much of what kings did was, in fact, mundane and routine. ${ }^{157}$ For the petitions 'signed off' by Burley, see TNA, SC 8/18/891 (1378); 115/5709 (1384); 222/11083 (1377-87), 11097 (1384), 11099 (1382); 223/11139 (1383); 224/11154 (c. 1384), 11155 (c. 1382); 226/11268 (? C. 1384 ), 11269 (c. 1380- c. 1386), 11271 (1380); 236/11791 (1377-1383), 11793 (1379). For the petitions with de Vere's named recorded, see TNA,SC 8/223/11102 (c. 1381), 11135 (1380); 224/11168 (c. 1383).

${ }^{158}$ For background, see Tuck, Richard II, pp. 87-89.

${ }^{159}$ St Albans Chronicle, pp. 620-23.

${ }^{160}$ See CCR, 1381-85, pp. 214-5.

${ }^{161}$ In 1381 the Great Seal was placed in the household and travelled around with the king, hence the large number of direct warrants per ipsum regem ('by the king himself') shown in Figure 6 (for discussion, see W. M. Ormrod, 'The Peasants' Revolt and the Government of England', Journal of British Studies 29 (1990), 1-30, esp. pp. 21-1). In 1382, the Great Seal remained at Westminster, in the custody of the keeper of privy seal and keeper of the chancery rolls, and was therefore used very much as it had been in more conventional times when the chancellor was in office.

${ }^{162}$ CCR, 1381-85, p. 214.

163 A view held by Barron, 'Reign of Richard II', pp. 302, 308.

${ }^{164}$ PROME, parliament of January 1380, items 13-15.

165 Tuck, Richard II, p. 44.

${ }^{166}$ PROME, parliament of 1381, item 38.

${ }^{167}$ Charles VI was eleven years and nine months when he succeeded to the throne on 16

September 1380; Richard II was ten years and six months when he acceded on 21 June 1377. For background on Charles VI, see F. Autrand, Charles VI: La Folie du roi (Paris, 1986), pp. 13-4, 19-21; Henneman, Olivier de Clisson, pp. 103-19.

${ }^{168}$ For example, note the Anonimalle Chronicle's account of the communication between the king and rebels in which the latter 'sent replies [to Richard] by the said messengers that they had risen to save him and to destroy traitors to him and the kingdom'; cf. The Peasants' Revolt of 1381, ed. R. B. Dobson, $2^{\text {nd }}$ edn. (London, 1983), p. 129.

${ }^{169}$ Louis of Anjou, the oldest of the late king's brothers, was installed as regent, but political rivalries between him and the other royal uncles, together with widespread social revolt, very 
soon necessitated a modification to this arrangement so that authority was shared out on a more consensual basis throughout the 1380s: see R. Vaughan, Philip the Bold: The Formation of the Burgundian State (London, 1962), pp. 39-42; Autrand, Charles VI, chapter 5; Henneman, Olivier de Clisson, pp. 103-19.

${ }^{170}$ St Albans Chronicle, pp. 344-5. 